\title{
The composition and structure of shallow benthic reef communities in the Kimberley, north-west Australia
}

\author{
Zoe Richards ${ }^{1,2^{*}}$, Monika Bryce ${ }^{1}$ and Clay Bryce ${ }^{1}$ \\ 1 Department of Aquatic Zoology, Western Australian Museum, Locked Bag 49, Welshpool DC, \\ Western Australia 6986, Australia. \\ ${ }^{2}$ School of Molecular and Life Sciences, Curtin University, Bentley, Western Australia 6845, Australia. \\ * Email: zoe.richards@museum.wa.gov.au
}

\begin{abstract}
The diversity, productivity and health of tropical reef ecosystems are at risk from cumulative anthropogenic and climate stressors. To provide insight into natural patterns of community structure and to set benchmarks to detect change, it is important to establish baselines for common community metrics, such as benthic cover, while ecosystems are near-pristine. Here we report the findings from six years of shallow-water marine benthic surveys $(0-15 \mathrm{~m}$ depth) in the Kimberley, Western Australia. This dataset provides the first broad-scale quantification of the general composition and structure of reefs in this little known region. We show that the Kimberley reef system is heterogeneous, with distinct inshore-offshore, intertidal-subtidal and subregional patterns of community structure. The dominant category of live benthos in the Kimberley is hard coral $(23.81 \% \pm 1.28 \%)$, followed by turf algae $(14.40 \% \pm 1.51 \%)$ and macro-algae $(7.05 \% \pm 1.00 \%)$. At the regional scale, soft corals and sponges were minor contributors to benthic cover accounting for less than $3 \%$. Benthic composition and structure was significantly different between all five subregions, with the exception of Inshore North and Inshore South, which share traits, such as a higher level of macroalgae and lower level of turf and coralline algae, than the level recorded in the Inshore Central subregion. Offshore, the southern subregion (Rowley Shoals) had the highest level of hard coral cover $(27.92 \% \pm 2.51 \%)$, and inshore the highest level of hard coral cover was recorded in the northern subregion $(25.39 \% \pm$ $3.00 \%)$. Overall, this dataset provides a reference for future marine conservation planning in the region and confirms that shallow benthic communities of the Kimberley are an important part of Australia's tropical reefscape.
\end{abstract}

KEYWORDS: baseline, benthos, coral cover, north-west Australia, Indian Ocean, Woodside Collection Project

\section{INTRODUCTION}

Tropical reefs are increasingly threatened by severe disturbances such as cyclones, in combination with more chronic threats like global warming. While reefs are naturally dynamic systems, there is growing concern that coral reef communities are being irrevocably damaged, changed, and/or simplified (Dornelas et al. 2014; Magurran et al. 2015; Smith et al. 2016). As a result, the ability for ecosystems to recover after disturbances is increasingly questioned (van Hooidonk et al. 2016; Hughes et al. 2017). Globally, most coral reef ecosystems are moderately to severely damaged by human activities, such as fishing and pollution; hence it can be difficult to separate natural from unnatural changes (Jackson 2001; Knowlton and Jackson 2008). The ability to detect significant change and substantiate recovery in long-term monitoring programs is dependent on the availability of comparative and rigorous pre-impact reference data. Obtaining baseline knowledge concerning the structure and functioning of ecosystems in the absence of human impacts is fundamental for the effective management and conservation of coral reef ecosystems.

In diverse tropical reef ecosystems, habitat attributes such as the percentage cover of benthic taxa and topographic complexity are relied upon to inform management about reef condition 
(Wilkinson 2008; Sweatman et al. 2008, 2011; Arias-González et al. 2011; Ateweberhan et al. 2011). Percent live hard coral cover is the most commonly used metric to monitor and inform managers about coral reef status (Bruno and Selig 2007; De'ath et al. 2012; Gilmour et al. 2013). The abundance and composition of live hard coral is related to disturbance history (De'ath et al. 2012) and correlated with density-dependent ecosystem processes, such as disease prevalence (Bruno et al. 2007), the abundance of corallivorous reef fishes (Bell and Galzin 1984; Jones et al. 2004; Komyakova et al. 2013) and the abundance and diversity of other marine invertebrates (Przeslawski et al. 2008; Gibson et al. 2011).

While many studies focus on the level of hard coral cover as a proxy of reef condition, other benthic categories can also provide meaningful indicators of reef status and resilience. For example, monitoring the cover of macroalgae and soft corals is especially relevant for detecting phase shifts and for interpreting the implications of changes to ecosystem structure on food-web dynamics (Sandin et al. 2008; Cheal et al. 2010). Macroalgal overgrowth on tropical reefs can indicate a lack of herbivorous grazing (Hughes et al. 2007) which may signify overfishing (Jackson et al. 2001), or be a competitive response to coral mortality events (Diaz-Pulido et al. 2009). Similarly, a shift from hard coral to soft coral dominance can be associated with reef degradation (Przeslawski et al. 2008; Baum et al. 2016). Additionally, the extent and composition of abiotic substrate can influence the diversity of fish and other invertebrates such as echinoderms, marine worms, molluscs and crustaceans (Komyakova et al. 2013; Graham et al. 2014). Hence, monitoring and reporting on a variety of metrics, in addition to coral cover, can provide useful information to managers concerning the status of different taxa, enabling the overall resilience of dynamic tropical reef ecosystems to be assessed.

The reef ecosystems of the Kimberley are among the least impacted in the world due to low population density (Halpern et al. 2008) and provide a unique opportunity to examine the composition and structure of reef environments in the absence of land-based anthropogenic impacts. Coral reefs in the region, as first described by Teichert and Fairbridge (1948), fall into two general groups - fringing reefs that have formed around coastal islands across the inner Sahul Shelf and the large platform reefs, shoals and shelf-edge atolls occurring offshore. The inshore fringing reefs are influenced by macrotides $(>11 \mathrm{~m})$, turbid waters and low wave energy (DEC 2009; Wilson 2014). The large semi-diurnal tides culminate in intertidal reef communities being subaerially exposed during spring low tides for up to 3.5 hours (Richards et al. 2015), and subjected to high current velocities and turbidity levels during tidal ebb and flow (Ivey et al. 2016). Conversely, the submerged midshelf shoals and continental edge offshore atolls represent stable, clearwater, low productivity coral reef environments (Wilson 2013).

While the region has largely escaped land-based anthropogenic disturbances, there is a long history of traditional fishing and harvesting in the region (Fox 1998), modest commercial fishing operations (Molony et al. 2011) and increasing recreational fishing and tourism activities. Additionally, the region is an important reservoir of oil and gas reserves (Moore et al. 2016) and the exploration and exploitation of these resources presents environmental risks to species and habitats in the region (Butt et al. 2013; Kark et al. 2015). In 2009 Australia's largest oil spill event occurred in the vicinity of Ashmore Reef and the midshelf shoals (Li et al. 2010), but the lack of before-impact data made it difficult to determine the extent of the environmental effects (Watson et al. 2009).

The offshore atolls have also been impacted by numerous climate-induced coral bleaching and mortality events. In 1998 and 2016 widespread coral bleaching events severely impacted Scott Reef (Smith et al. 2008; Gilmour et al. 2013; Hughes et al. 2017) and in 2003 and 2010 Ashmore Reef was affected by coral bleaching (Ceccarelli et al. 2011; Heyward 2011). While the inshore Kimberley reefs appeared to escape the global bleaching events of 1998 and 2013, localised coral bleaching was recorded at reefs in the southern inshore Kimberley for the first time in 2016 (Le Nohaic et al. 2017). Hence, even though it is hypothesised that corals in the inshore Kimberley are tolerant of extreme environmental conditions (Richards et al. 2015); they are not immune to bleaching (Schoepf et al. 2015).

Here we report the findings from six years of baseline surveys in the marine environments of the Kimberley to provide a primary dataset quantifying the benthic composition and structure of Kimberley reefs. This dataset can be used as a reference for future monitoring and is available to inform managers about the variety of benthic communities in the region in order to facilitate the development of representative marine management reserves. 
More specifically we seek to answer the following questions:

1. What are the major abiotic and biotic components that structure shallow water marine benthic communities in the Kimberley?

2. Are macro-scale environmental influences, such as tidal zone and shelf position major drivers of spatial structuring in Kimberley benthic communities?

3. Is there spatial partitioning at a subregional level?

\section{METHODS}

\section{FIELD SURVEYS}

Benthic community composition was recorded at single time-points from 2009-2014 at 164 stations, from 33 island/reef groups from a survey area within the Kimberley Project Area (Figure 1, see Sampey et al. 2014 for further descriptions of the Project Area and Bryce et al. 2017 for further descriptions of the stations surveyed). One hundred survey stations were subtidal (mean depth $11.5 \mathrm{~m}$, range 5-16 $\mathrm{m}$, depending upon tidal amplitude) and 64 stations were intertidal (mean depth $0.5 \mathrm{~m}$, range $0-4 \mathrm{~m}$ ) (see Appendix 1). The subtidal sites were generally reef slopes, patch reef or submerged lagoonal habitats that were surveyed on SCUBA. Intertidal sites were mid to lower littoral reef flats surveyed by reef-walking or snorkeling at low tide when the reefs were subaerially exposed.

The number of stations surveyed at each reef varied depending on the size of the reef, the prevailing weather, oceanic conditions (tidal amplitude, currents, water visibility) and any overarching occupational safety considerations, such as the presence of crocodiles, diver nitrogen loads and vessel restrictions. Thus, while only a single station was surveyed at some reefs, six reefs were more intensively surveyed with over 10 separate stations surveyed (Ashmore Reef, Long Reef, Cassini Island, Montgomery Reef, Adele Island, and Rowley Shoals; see Figure 2). These reefs represent the extremes of any possible cross

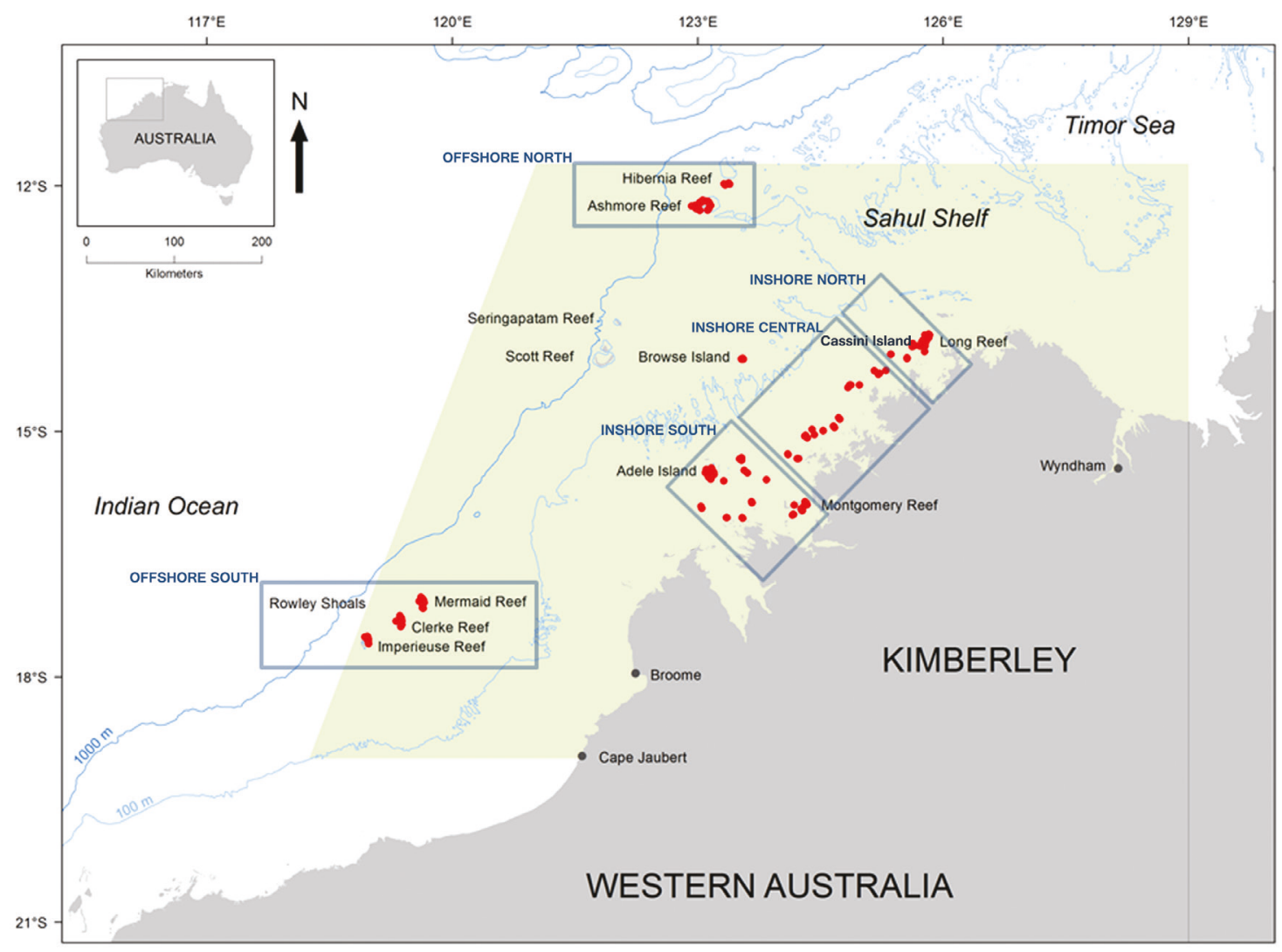

FIGURE 1 The Kimberley Project Area (green shaded area) with survey stations (red dots) and subregions (blue boxes). Browse Island was included in the Offshore North subregion. Locations with multiple survey stations are shown in Figure 2. 

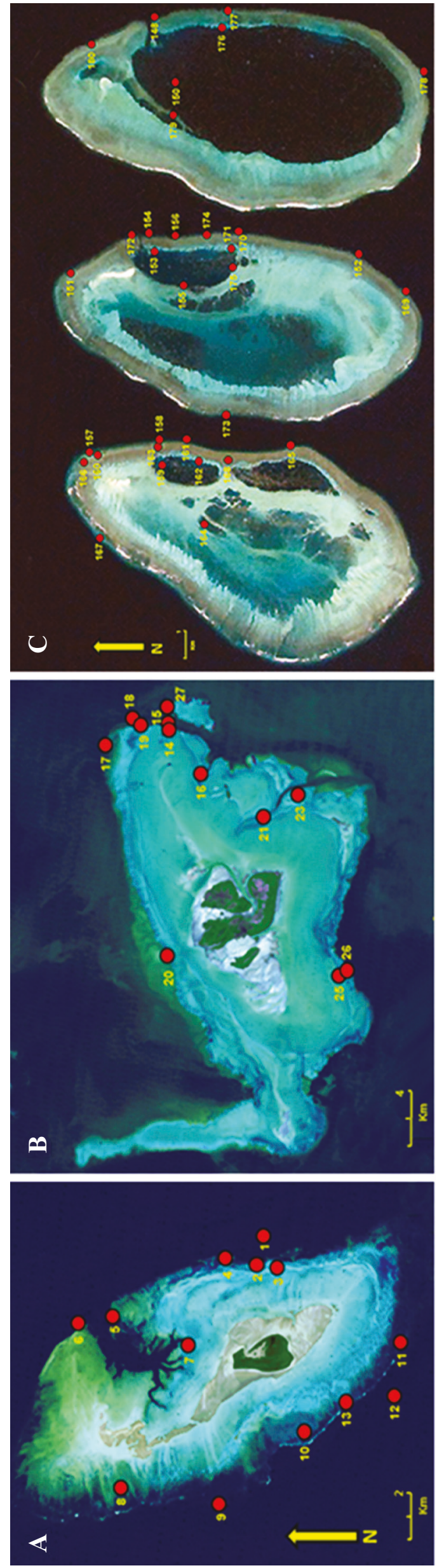
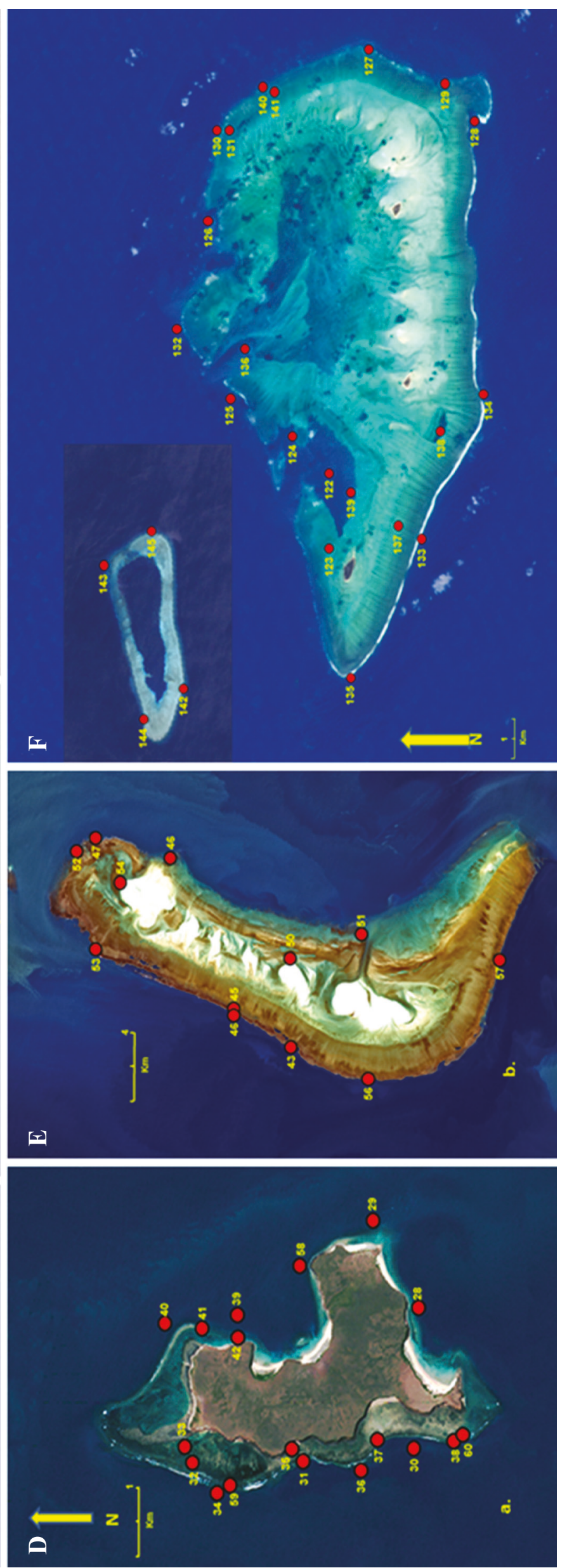

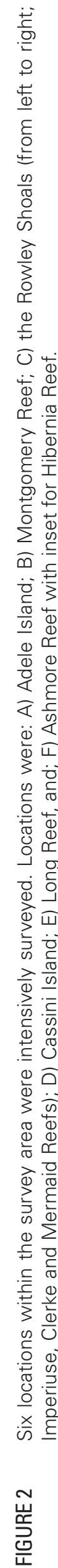


shelf and latitudinal benthic gradients. For further discussion of site choice refer to Bryce et al. (2017).

A combination of photo transects $(2009,2010$, 2011 and 2012) and in-situ point-intercept (2013, 2014) assessments were undertaken. In the case of photo transects, 25 replicate $1 \mathrm{~m}^{2}$ photographs were taken along each of three randomly placed $25 \mathrm{~m}$ transects. Coral Point Count with Excel extension software (Kohler and Gill 2006) was then used to determine the benthic composition directly below two randomly placed points per image (50 points per transect). For in-situ assessments (2013-2014), the benthic composition directly below 50 points (every $50 \mathrm{~cm}$ ) was determined across each of three randomly placed $25 \mathrm{~m}$ transects. The photo-transect and in-situ point count methodologies are well accepted (Hill and Wilkinson 2004) and the data are comparable as the number of point counts were identical (Jokiel et al. 2015).

Given the large number of stations surveyed over such a large area, the stations were separated into five subregions, which were defined according to latitude and bathymetry and designated as: Offshore North, Offshore South, Inshore North, Inshore Central and Inshore South (Figure 1). For this analysis inshore and offshore were defined by bathymetry with respect to distance from the coast, where inshore extended from the mainland to the $100 \mathrm{~m}$ bathymetric contour and offshore extended deeper from $101 \mathrm{~m}$ (see Figure 1). To ameliorate occupational safety concerns only islands and reefs occurring at least $10 \mathrm{~km}$ from the mainland and distanced from river outflows were surveyed.

Benthic cover was classified into 13 coarse biotic and abiotic categories. Biotic categories were: hard corals, soft corals, sponges, seagrasses, macroalgae, turf algae, coralline algae (encrusting forms), crustose algae (branching calcareous forms incl. Halimeda sp.) and other invertebrates (including zooanthids, molluscs, holothurians, ascidians and bryozoans). Abiotic categories were: sand, shell grit, rubble, bare rock and silt.

\section{DATA ANALYSIS}

Summary statistics were calculated for the mean percent cover $( \pm$ SE) of each benthic category in the area surveyed, according to shelf position (inshore/offshore), tidal zone (intertidal/subtidal) and subregion. To test whether environmental heterogeneity differed between factors we performed an analysis of homogeneity of multivariate dispersions (PERMDISP) in Primer-E Version 7 (Clarke and Gorley 2015). The benthic cover variables were square-root transformed to reduce the influence of the common taxa and increase the influence of the rare taxa and a resemblance matrix of similarities was calculated using the Bray-Curtis coefficient. The Bray Curtis similarity coefficient was used because it does not consider joint absences and this is the standard coefficient used in biological assemblage and community analyses (Clarke and Gorley 2015). The resulting resemblance matrix was visualised using Principal Coordinates Analysis (PCO).

To test for the significance of differences in benthic community structure ANOSIM were conducted on the factors of shelf position (inshore/ offshore), tidal zone (intertidal/subtidal) and subregion. The assumption of homogeneity of dispersions was satisfied in PERMDISP tests; hence we further explored the factors influencing community structure and the presence of interaction effects with Permutational ANOVA (PERMANOVA) (Clarke and Gorley 2015). This analysis was conducted with type III sums of squares using a fixed effects design where tidal zone and subregion were nested in shelf position. Furthermore, to examine which variables are contributing to the observed differences in community structure we conducted one-way analysis of similarity (SIMPER) and visualised the patterns for the key groups via PCO.

To better visualise significant differences identified through our PERMANOVA analysis we used bootstrapping of group means and ordination of these results with non-metric MDS, as suggested by Clarke and Gorley (2015). This approach is a multivariate analogue of univariate means plots with error bars, and is an effective way to display differences in groups that contain high sampling variability, which defines clear ordinations in two dimensions (i.e. high stress). Use of group means averaged over multiple bootstraps greatly reduces the sampling variability and provides for improved interpretability of ordinations.

\section{RESULTS}

\section{REGIONAL PATTERNS IN BENTHIC COVER}

The dominant category of live benthos in the Kimberley survey area was hard coral $(23.81 \%$ $\pm 1.28 \%$ ) (Table 1). However, a large variation in the level of hard coral cover was recorded across the survey sites (Appendix 1). Turf algae was the second largest contributor to benthic cover in the region $(14.40 \% \pm 1.51 \%)$ followed by macroalgae $(7.05 \% \pm 1.00 \%)$. At the regional scale, soft corals, sponges and other benthic invertebrates were minor contributors to benthic cover as each accounted for less than 3\% of the overall cover. Appendix 1 contains summary data for the mean cover of the remaining benthic categories at all stations surveyed. 

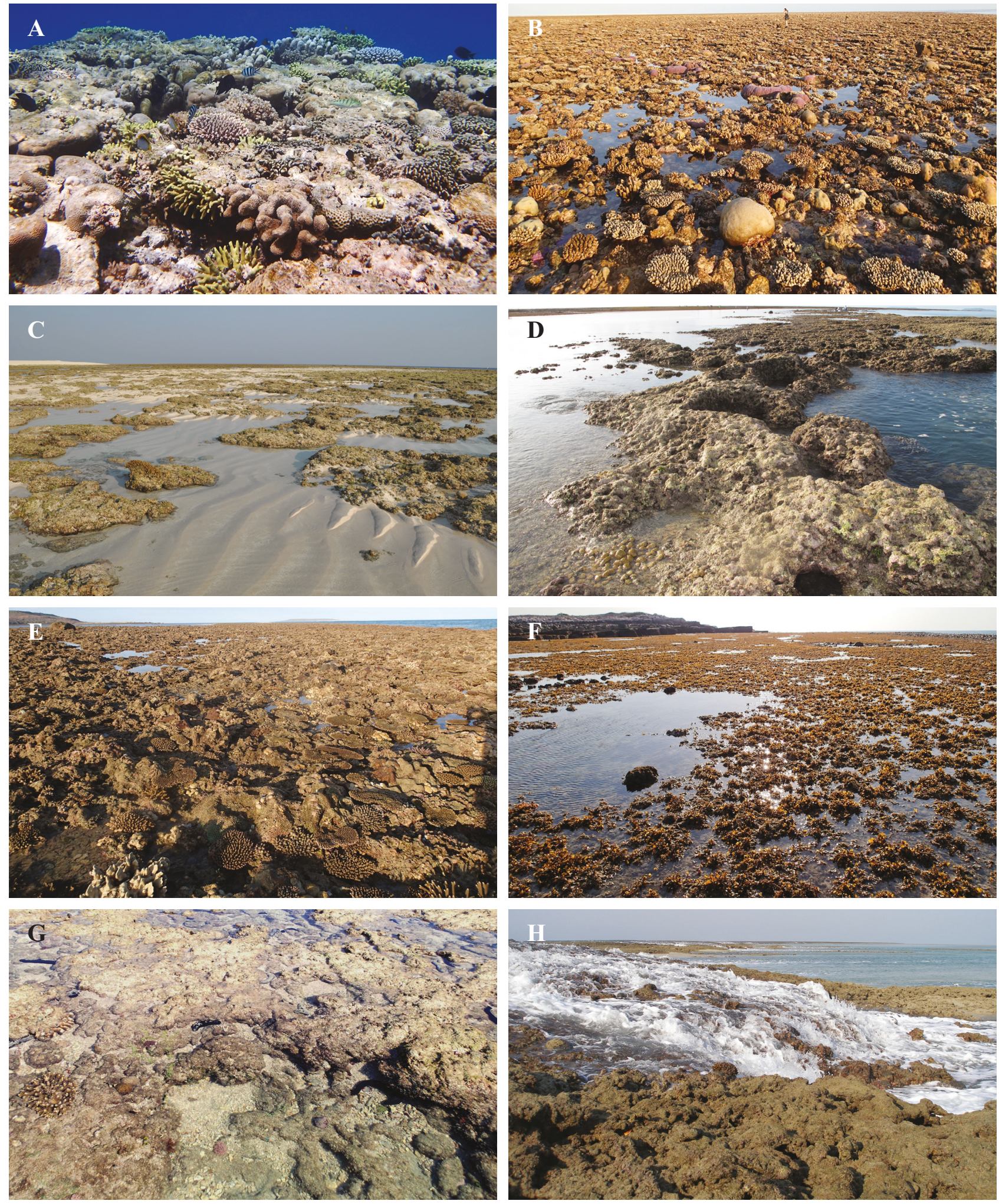

FIGURE 3 Intertidal habitat: offshore and inshore. A) Low-growing corals on the shallow outer reef flat at Ashmore Reef (129/K13); B) Consolidated reef pavement with high coral cover at Clerke Reef (Rowley Shoals: 172/ K14); C) Flat cemented reef platform with turf algae and motile sand at Browse Island (104/K12); D) Midlittoral reef pavement extending down to a narrow, honeycombed fore-reef ramp at Long Reef (56/K10). The tide pools are fringed with small coral colonies and the ramp has a high cover of Tubipora musica (28\%) (Richards et al. 2013); E) Intertidal reef platform at Patricia Island (114/K12) with an abundance of hard coral colonies; F) The reef platform on the north side of Woodward Island (100/K12) is dominated by cropped Sargassum and turf algae; G) Cemented reef platform with many tide pools, coralline algae and turf algae at Condillac Island (112/K12); H) A steep forward ramp with drainage channels leading to a seaward terrace dominated by turf and coralline algae at Montgomery Reef (16/K09). 

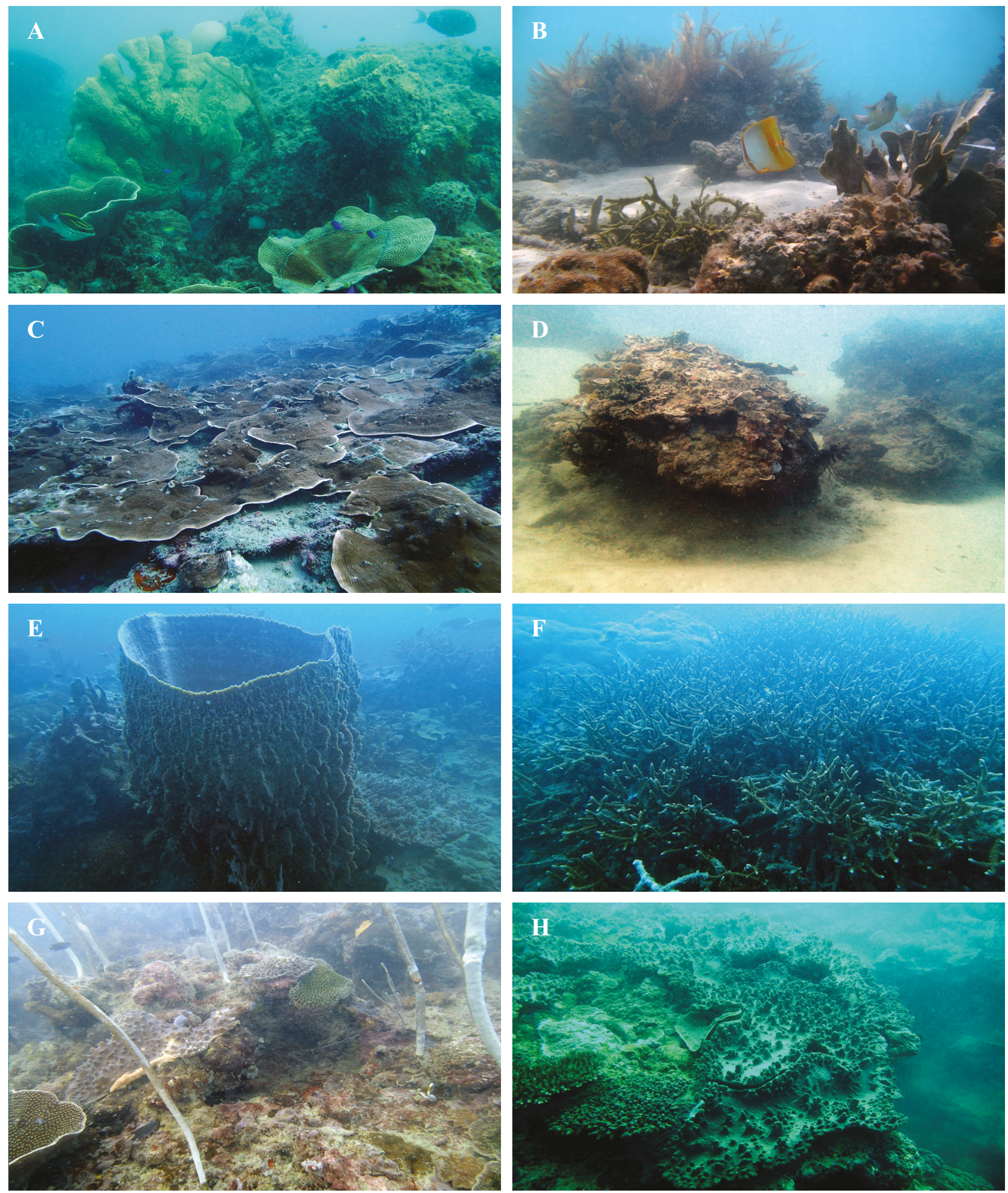

FIGURE 4 Subtidal Inshore habitat. A) Gently sloping reef at Long Reef (58/K10) with coral outcrops covered with sponges, hard corals, soft corals, sea fans, hydroids and encrusting molluscs; B) Long Reef (50/K10): inner lagoon habitat near a sand cay with coarse coralline sand, small rocky outcrops and a high abundance of the sponge, Phyllospongia sp.; C) High energy outer reef edge at Robroy Reefs (118/K12) with large Montipora plates; D) Station 119/K12 at Robroy Reefs: a plain of coarse coralline sand with large rocky outcrops covered with hard corals, sponges, hydroids and algae; E, F) A patch reef on the eastern side of the West Montalivet Island (117/K12). Sea whips, sea fans and sponges, such as the large barrel sponge, Xestospongia testudinaria, were well represented at the station, in addition to expansive areas of branching Acropora sp.; G) The seaward reef edge at Patricia Island (114/K12) is made up of single and coalesced outcrops covered with coralline algae, hard corals, soft corals, sponges, and a fine dusting of silt; H) Large rocky outcrops at Adele Island (06/K09) formed a deeply incised, ledged and undercut vertical wall covered with hard corals and encrusting soft corals. 

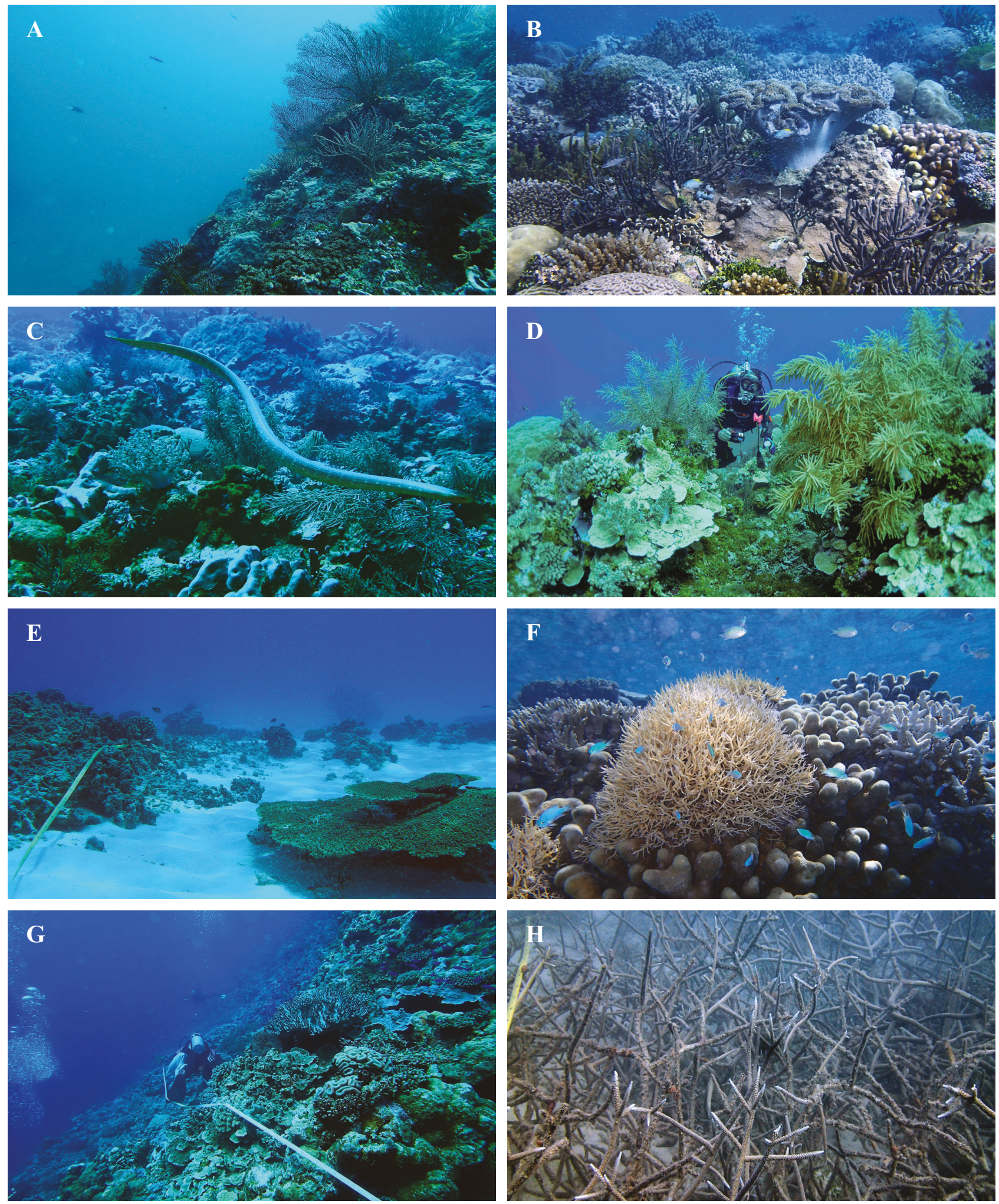

FIGURE 5 Subtidal Offshore habitat. A, B) Steep outer slope at north Ashmore Reef (130/K13) is deeply incised with caves and small ledges. The slope and slope crest $(5-7 \mathrm{~m})$ display a diverse assemblage of hard and soft corals; C) Station 142/K13, north Hibernia Reef. Reef crest of the fore-reef slope is mainly covered by hard corals and a diverse assemblage of algae including Halimeda sp.; D) The cemented fore-reef slope at north Hibernia Reef (144/K13) with 'hillocks' and 'gullies' and a diversity of soft and hard corals between; E) Low profile patch reef at Browse Island (101/K12) consisting of small, coalescing outcrops with colonies of hard corals and turf algae; F) The edge of a large mid-littoral tide pool (depth: $6 \mathrm{~m}$ ) at Ashmore Reef (138/K13). Acropora thickets dominated throughout the base of the pool; G) A steep, high profile reef at the south east end of Mermaid Reef (Rowley Shoals: 178/K14) displays an impressive coverage of hard corals with a high abundance of turf and coralline algae; H) Thickets of Acropora sp. were dominant in the lagoon of Mermaid Reef (179/K14). 
TABLE 1 Summary statistics for the overall mean cover $( \pm \mathrm{SE})$ of the nine major biotic categories encountered in the Kimberley survey area, within tidal zone, shelf position and subregion. Maximum values within zone, position and subregion are marked in bold.

\begin{tabular}{|c|c|c|c|c|c|c|c|c|c|c|}
\hline & & $\begin{array}{l}\text { Hard } \\
\text { Coral }\end{array}$ & $\begin{array}{l}\text { Soft } \\
\text { Coral }\end{array}$ & Sponge & $\begin{array}{l}\text { Other } \\
\text { Inverts }\end{array}$ & $\begin{array}{l}\text { Turf } \\
\text { Algae }\end{array}$ & $\begin{array}{l}\text { Coralline } \\
\text { Algae }\end{array}$ & $\begin{array}{l}\text { Macro } \\
\text { Algae }\end{array}$ & Halimeda & Seagrass \\
\hline \multirow{2}{*}{ Region Wide } & Mean & 23.81 & 2.66 & 2.30 & 0.65 & 14.40 & 4.21 & 7.05 & 1.61 & 0.18 \\
\hline & SE & 1.28 & 0.33 & 0.23 & 0.10 & 1.51 & 0.50 & 1.00 & 0.42 & 0.10 \\
\hline \multirow{2}{*}{ Intertidal } & Mean & 14.38 & 0.77 & 1.45 & 0.17 & 19.19 & 1.85 & 15.48 & 0.23 & 0.41 \\
\hline & SE & 1.92 & 0.19 & 0.34 & 0.10 & 3.31 & 0.52 & 2.15 & 0.13 & 0.26 \\
\hline \multirow{2}{*}{ Subtidal } & Mean & 29.85 & 3.88 & 2.85 & 0.96 & 11.34 & 5.72 & 1.65 & 2.48 & 0.04 \\
\hline & SE & 1.41 & 0.50 & 0.31 & 0.15 & 1.21 & 0.71 & 0.27 & 0.68 & 0.03 \\
\hline \multirow{2}{*}{ Inshore } & Mean & 24.45 & 2.05 & 2.52 & 0.40 & 8.30 & 3.06 & 9.45 & 0.43 & 0.02 \\
\hline & SE & 1.78 & 0.35 & 0.30 & 0.10 & 1.67 & 0.65 & 1.54 & 0.15 & 0.01 \\
\hline \multirow{2}{*}{ Offshore } & Mean & 22.76 & 3.67 & 1.94 & 1.06 & 24.45 & 6.10 & 3.10 & 3.54 & 0.45 \\
\hline & SE & 1.72 & 0.66 & 0.37 & 0.20 & 2.42 & 0.73 & 0.46 & 1.06 & 0.27 \\
\hline \multirow{2}{*}{ Inshore North } & Mean & 23.59 & 2.56 & 3.37 & 0.36 & 3.54 & 2.72 & 7.58 & 0.08 & 0.00 \\
\hline & SE & 3.00 & 0.80 & 0.64 & 0.18 & 1.90 & 0.75 & 2.55 & 0.04 & 0.00 \\
\hline \multirow{2}{*}{ Inshore Central } & Mean & 23.65 & 3.05 & 1.45 & 0.61 & 22.66 & 7.35 & 3.60 & 1.228 & 0.10 \\
\hline & $\mathrm{SE}$ & 3.67 & 0.75 & 0.43 & 0.26 & 5.18 & 2.33 & 1.35 & 0.48 & 0.06 \\
\hline \multirow{2}{*}{ Inshore South } & Mean & 24.16 & 1.17 & 2.43 & 0.31 & 4.55 & 1.13 & 13.85 & 0.27 & 0.00 \\
\hline & SE & 2.82 & 0.31 & 0.41 & 0.13 & 1.61 & 0.42 & 2.71 & 0.21 & 0.00 \\
\hline \multirow{2}{*}{ Offshore North } & Mean & 17.26 & 5.57 & 3.16 & 1.20 & 16.19 & 5.55 & 2.68 & 7.11 & 0.89 \\
\hline & SE & 1.90 & 1.19 & 0.63 & 0.30 & 1.95 & 0.93 & 0.65 & 1.99 & 0.54 \\
\hline \multirow{2}{*}{ Offshore South } & Mean & 27.92 & 1.89 & 0.80 & 0.94 & 32.20 & 6.61 & 3.50 & 0.19 & 0.03 \\
\hline & SE & 2.52 & 0.43 & 0.29 & 0.28 & 3.86 & 1.12 & 0.64 & 0.17 & 0.02 \\
\hline
\end{tabular}

Important differences were observed in the level of cover of all major benthic categories between intertidal and subtidal zones. While some intertidal reefs had a high level of coral cover (e.g. Patricia Island, Figure 3E), hard coral cover was generally twice as high in subtidal zones (see Figures 4, 5). Similarly, soft corals, sponges, invertebrates and coralline algae were more commonly encountered in subtidal habitats. Other types of marine flora (turf algae, macroalgae, Halimeda spp. and seagrasses) were more commonly encountered in the intertidal habitats. Amongst the abiotic groups, rock, silt and sand dominated both intertidal and subtidal zones, but these groups reached their highest level of coverage in the intertidal zone (Table 2). In the subtidal zone there was a higher coverage of rubble and shell grit.

Substantial differences were also observed in the percentage composition of benthic categories
TABLE 2 Summary statistics for the overall mean cover $( \pm$ SE) of the four major abiotic categories of benthos encountered in the Kimberley survey area, within tidal zone and shelf position. Maximum values are marked in bold.

\begin{tabular}{|c|c|c|c|c|c|}
\hline & & Sand & Rubble & $\begin{array}{l}\text { Rock } \\
\text { \& Silt }\end{array}$ & $\begin{array}{l}\text { Shell } \\
\text { Grit }\end{array}$ \\
\hline \multirow{2}{*}{ Intertidal } & Mean & 15.18 & 11.13 & 19.47 & 0.18 \\
\hline & $\mathrm{SE}$ & 1.87 & 1.30 & 2.63 & 0.10 \\
\hline \multirow{2}{*}{ Subtidal } & Mean & 12.10 & 11.52 & 16.64 & 1.05 \\
\hline & SE & 1.53 & 1.29 & 1.89 & 1.00 \\
\hline \multirow{2}{*}{ Inshore } & Mean & 12.09 & 8.64 & 27.56 & 1.03 \\
\hline & $\mathrm{SE}$ & 1.36 & 1.01 & 1.85 & 0.98 \\
\hline \multirow{2}{*}{ Offshore } & Mean & 15.31 & 15.85 & 1.60 & 0.18 \\
\hline & SE & 2.19 & 1.68 & 0.81 & 0.10 \\
\hline
\end{tabular}


at inshore and offshore locations. Hard corals were the dominant taxa across the shelf, but overall, they reached a slightly higher level of cover inshore. The soft coral cover was at its highest level offshore as was turf algae, coralline algae, Halimeda spp., seagrasses and other invertebrates (holothurians, molluscs etc.). Sponges and macroalgae were more commonly encountered inshore. It should be noted that seagrasses were rarely encountered at any of the survey sites. Amongst the abiotic groups, rock and silt dominated the inshore bioregions, whilst the offshore bioregions had a higher coverage of sand and rubble (Table 2).

There was significant subregional variation in the level of cover recorded on individual transects. For hard corals the level of percent cover was greatest in the Offshore South subregion (Rowley Shoals, $27.92 \% \pm 2.52 \%$ ) and lowest in the Offshore North (Ashmore and Hibernia Reefs, 17.26\% \pm $1.90 \%$ ). For soft corals, the reverse pattern was observed with the highest level of cover in the Offshore North $(5.57 \% \pm 1.19 \%)$. Sponges reached their highest level of cover $(3.37 \% \pm 0.64 \%)$ in the Inshore North, while other invertebrates (holothurians, molluscs, anemones etc.) were more likely to be encountered in the Offshore North. Amongst the marine flora, turf algae reached its highest level of cover in the Offshore South, whilst seagrasses and Halimeda spp. were more prevalent in the Offshore North. The highest level of coralline algal cover was recorded in the Inshore Central, whilst macroalgae dominated in the Inshore South.

\section{THE INFLUENCE OF SHELF POSITION AND TIDAL ZONE ON BENTHIC COVER}

When visualised as a $\mathrm{PCO}$, over $70 \%$ of the observed variation in benthic structure was accounted for by the first two axes (Figure 6). PERMANOVA results confirmed there is a highly significant difference between inshore and offshore communities $\left(t=6.7804, \mathrm{P}_{\text {perm }}=0.0001\right)$ and between subtidal and intertidal communities $(t=5.3287$, $\left.\mathrm{P}_{\text {perm }}=0.0001\right)$. The SIMPER analysis of the group contributions to the average similarity between inshore and offshore locations (Table 3) supports the main vectors in the PCO (Figure 6) indicating

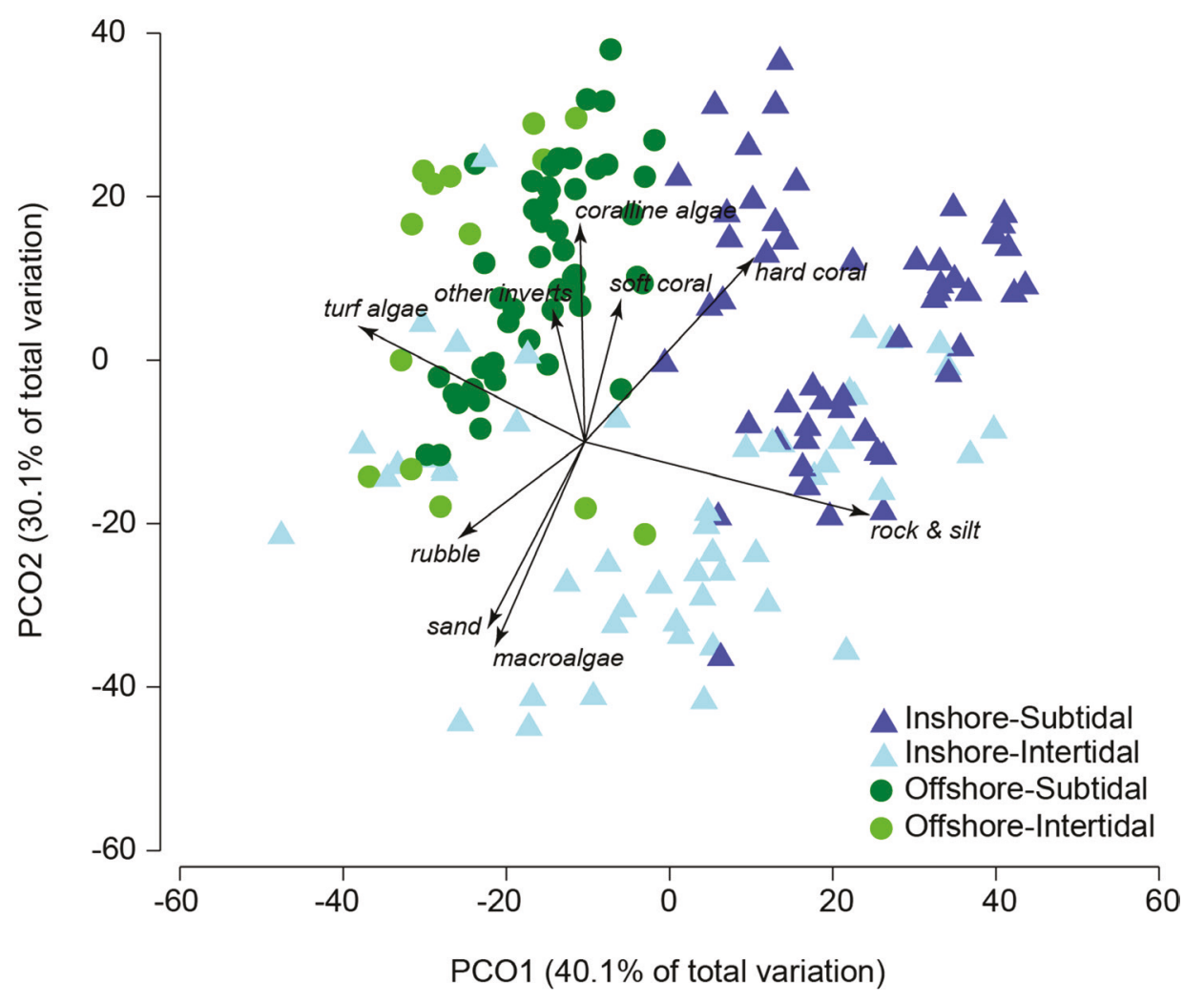

FIGURE 6 Principal coordinates analysis of benthic community composition in the Kimberley survey area. Stations clustered according to shelf position (inshore offshore) and tidal zone (intertidal/subtidal). The vectors indicate the principal drivers of similarity between stations. 
TABLE 3 SIMPER analysis of the species contributions to the average similarity between shelf position, tidal zone and subregion. Included are the top three benthic groups explaining the largest percent of the variance. The principal driver is marked in bold.

\begin{tabular}{|c|c|c|c|c|c|}
\hline Species & Avg Abund. & Avg Abund. & Avg Diss. & Diss./SD & Cont. $\%$ \\
\hline & Inshore & Offshore & & & \\
\hline Rock/Silt & 4.75 & 0.48 & 9.69 & 1.88 & 18.55 \\
\hline Turf Algae & 1.52 & 4.64 & 8.50 & 1.68 & 16.28 \\
\hline \multirow[t]{2}{*}{ Sand } & 3.85 & 3.18 & 5.43 & 1.31 & 10.40 \\
\hline & Subtidal & Intertidal & & & \\
\hline Rock/Silt & 2.96 & 3.42 & 7.20 & 1.28 & 14.22 \\
\hline Turf Algae & 2.57 & 2.90 & 7.10 & 1.23 & 14.02 \\
\hline \multirow[t]{2}{*}{ Macroalgae } & 0.85 & 3.24 & 6.05 & 1.24 & 11.95 \\
\hline & Inshore Intertidal & Inshore Subtidal & & & \\
\hline Macroalgae & 3.69 & 0.31 & 7.95 & 1.49 & 16.21 \\
\hline Hard Coral & 3.35 & 5.66 & 6.61 & 1.50 & 13.48 \\
\hline \multirow[t]{2}{*}{ Rock/Silt } & 4.11 & 5.47 & 6.14 & 1.28 & 12.53 \\
\hline & Offshore Intertidal & Offshore Subtidal & & & \\
\hline Hard Coral & 2.76 & 4.97 & 5.83 & 1.57 & 14.23 \\
\hline Turf Algae & 6.19 & 4.19 & 5.67 & 1.32 & 13.85 \\
\hline \multirow[t]{2}{*}{ Rubble } & 2.67 & 3.85 & 4.29 & 1.37 & 10.46 \\
\hline & Inshore Intertidal & Offshore Intertidal & & & \\
\hline Turf Algae & 1.98 & 6.19 & 11.52 & 1.69 & 21.22 \\
\hline Rock/Silt & 4.11 & 0.94 & 8.85 & 1.44 & 16.30 \\
\hline \multirow[t]{2}{*}{ Macroalgae } & 3.69 & 1.62 & 6.14 & 1.32 & 11.31 \\
\hline & Inshore Subtital & Offshore Subtidal & & & \\
\hline Rock/Silt & 5.47 & 0.35 & 11.00 & 2.93 & 22.22 \\
\hline Turf Algae & 1.11 & 4.19 & 7.21 & 1.79 & 14.58 \\
\hline \multirow[t]{2}{*}{ Rubble } & 1.63 & 3.85 & 6.04 & 1.48 & 12.21 \\
\hline & Offshore North & Offshore South & & & \\
\hline Sand & 4.15 & 2.27 & 6.01 & 1.35 & 15.69 \\
\hline Turf Algae & 3.81 & 5.42 & 4.29 & 1.12 & 11.21 \\
\hline \multirow[t]{2}{*}{ Hard Coral } & 3.80 & 5.09 & 4.12 & 1.20 & 10.75 \\
\hline & Offshore South & Inshore South & & & \\
\hline Turf Algae & 5.42 & 0.96 & 10.79 & 1.98 & 19.92 \\
\hline Rock/Silt & 0.00 & 4.62 & 10.46 & 1.88 & 19.29 \\
\hline \multirow[t]{2}{*}{ Rubble } & 3.79 & 2.41 & 5.39 & 1.32 & 9.94 \\
\hline & Offshore North & Inshore North & & & \\
\hline Rock/Silt & 0.99 & 5.33 & 9.57 & 2.02 & 17.96 \\
\hline Turf Algae & 3.81 & 0.65 & 7.60 & 2.29 & 14.25 \\
\hline Sand & 4.15 & 2.76 & 6.04 & 1.33 & 11.34 \\
\hline
\end{tabular}




\begin{tabular}{|c|c|c|c|c|c|}
\hline Species & Avg Abund. & Avg Abund. & Avg Diss. & Diss./SD & Cont. \% \\
\hline & Inshore North & Inshore Central & & & \\
\hline Turf Algae & 0.65 & 3.92 & 8.67 & 1.31 & 18.40 \\
\hline Rock/Silt & 5.33 & 4.15 & 5.85 & 1.19 & 12.36 \\
\hline \multirow[t]{2}{*}{ Sand } & 2.76 & 2.35 & 5.22 & 1.28 & 11.09 \\
\hline & Inshore North & Inshore South & & & \\
\hline Macroalgae & 1.54 & 2.74 & 6.55 & 1.15 & 15.29 \\
\hline Rock/Silt & 5.33 & 4.62 & 5.98 & 1.19 & 13.96 \\
\hline \multirow[t]{2}{*}{ Hard Coral } & 4.65 & 4.36 & 5.85 & 1.24 & 13.66 \\
\hline & Inshore Central & Inshore South & & & \\
\hline Turf Algae & 3.92 & 0.96 & 8.34 & 1.32 & 17.15 \\
\hline Rock/Silt & 4.15 & 4.62 & 6.08 & 1.22 & 12.50 \\
\hline Macroalgae & 1.07 & 2.74 & 5.91 & 1.18 & 12.15 \\
\hline
\end{tabular}

the cross shelf separation is driven by the high cover of rock and silt at inshore locations, and the higher cover of turf algae and sand offshore (see also Tables 1,2). The SIMPER analysis also supports the main vectors of the PCO, which suggest there is higher cover of rock and silt, turf algae and macroalgae in intertidal zones. Within the inshore region, the intertidal zone is distinguished from the subtidal zone by a higher coverage of macroalgae and a lower coverage of hard corals and rock/silt. However, offshore, the main dissimilarity between the intertidal and subtidal communities is a higher level of hard coral and rubble cover in the subtidal zone while the intertidal zone has a higher level of turf algae cover. Overall, turf algae, hard corals and macroalgae are the main biotic drivers of significant differences and PCOs of community composition provides strong visual support for the way these groups are structured across the shelf and depth gradients (Figure 7).

\section{SUBREGIONAL TRENDS IN BENTHIC COVER}

The PERMANOVA results demonstrate highly significant differences between benthic assemblages from all subregions with the exception of the Inshore North and Inshore South, which were non-significant at the $\mathrm{p}<0.05$ level (Table 4). These patterns are visualised in the nonMetric multidimensional scale plot which shows bootstrapped subregional means ( $n=100$ resamples with replacement) with $95 \%$ confidence (Figure 8). The ordination provides powerful visual support for the PERMANOVA results signifying a strong similarity between the intertidal communities of the Inshore North and Inshore South, along with a strong similarity between the subtidal communities of these subregions. There is also a small amount of overlap between the subtidal communities in the Inshore North and Inshore Central (Figure 8).

The SIMPER analysis shows the main groups driving the differences between the Offshore South and Offshore North are the higher levels of turf algae and hard coral cover in the former and the higher level cover of sand in the latter (Table 3). Within the inshore subregions the higher level of turf algae in Inshore Central distinguishes it from the Inshore South or Inshore North, with the former distinguished by higher hard coral cover and the latter by higher macroalgae cover. Abiotic groups are also important drivers of difference between inshore subregions, with the lower level of rock and silt in the Inshore Central distinguishing it from the Inshore North and Inshore South (Table 3).

\section{FINE-SCALE PATTERNS IN HARD CORAL COVER}

Based on the results from the six locations that were intensively surveyed (see Figure 2), there is considerable heterogeneity in the level of hard coral cover within reefs (Figure 9). Cassini Island had the highest reef-wide hard coral cover with $29.64 \% \pm 5.36 \%$ followed by the Rowley Shoals $(27.92 \% \pm 2.51 \%)$, Adele Island $(27.64 \% \pm 5.78 \%)$, Montgomery Reef $(17.67 \% \pm 3.28 \%)$ and Ashmore Reef $(15.83 \% \pm 2.20 \%)$. Furthermore, there was a 

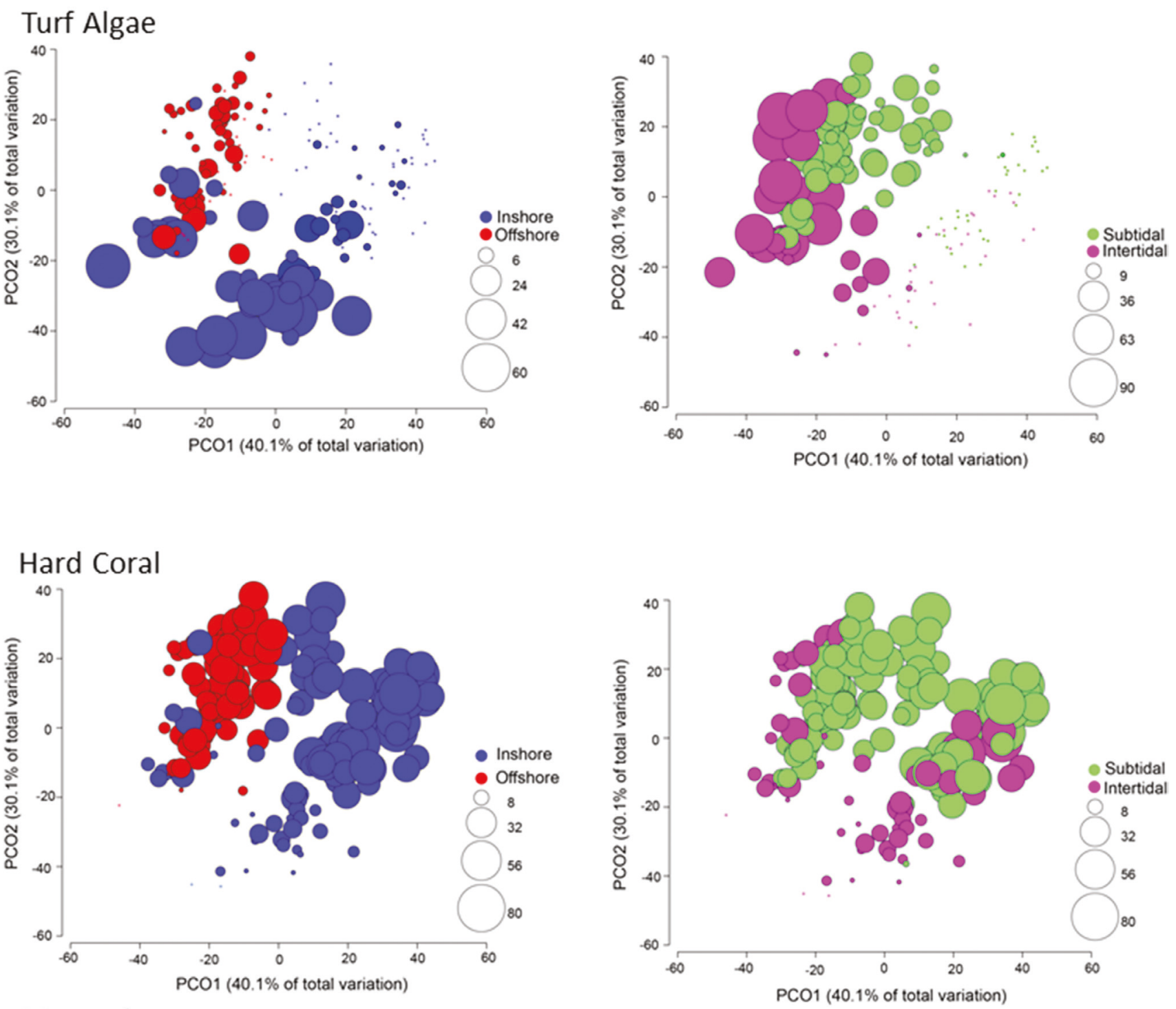

\section{Macroalgae}
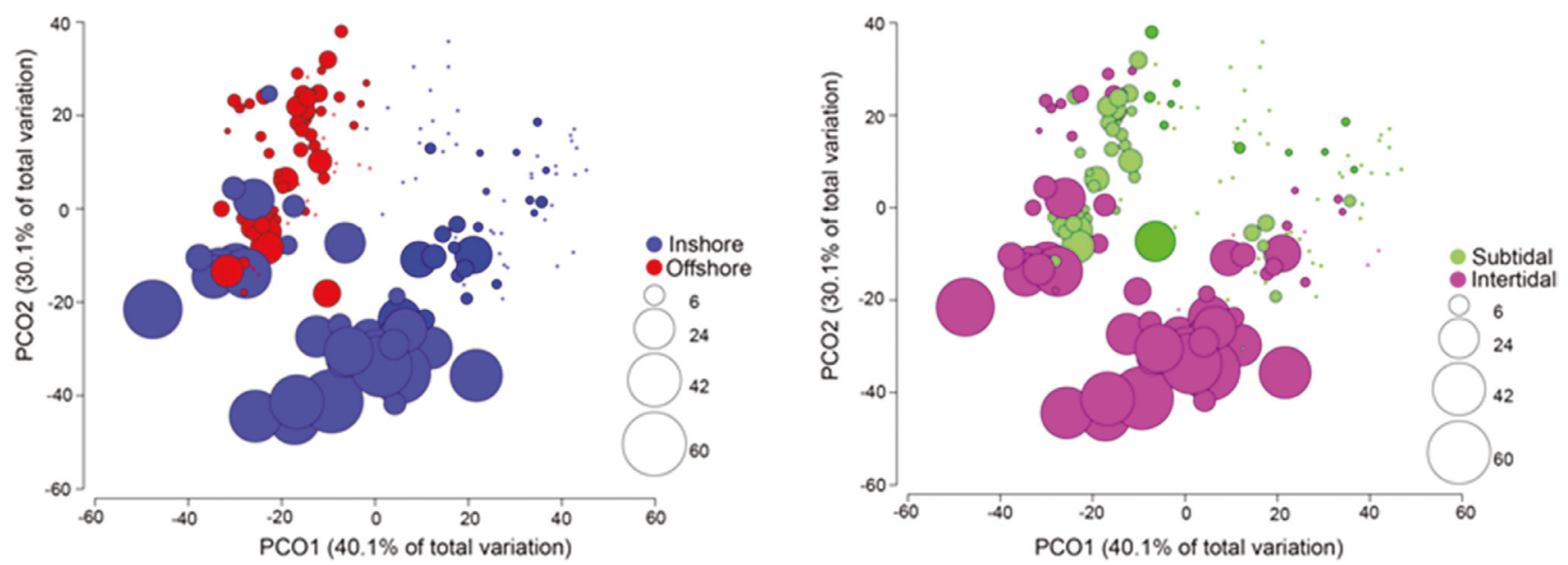

FIGURE 7 Principal coordinates analysis of community composition of the three main biotic drivers of regional patterns in community structure. Bubbles are proportional to the abundance of each taxa. 
TABLE 4 PERMANOVA results from pairwise tests of the factors influencing community structure and the presence of interaction effects.

\begin{tabular}{llll} 
Factor & Test & $\mathrm{t}$ & $\mathrm{P}(\mathrm{perm})$ \\
\hline Shelf position (Inshore) & Inshore South, Inshore Central & 3.1952 & $0.0001^{* * *}$ \\
& Inshore South, Inshore North & 1.2992 & $0.1605 \mathrm{~ns}$ \\
& Inshore Central, Inshore North & 3.3794 & $0.0001^{* * *}$ \\
Shelf position (Offshore) & Offshore North, Offshore South & 4.1204 & $0.0001^{* * *}$ \\
Shelf position x habitat & Subtidal: inshore, offshore & 8.1415 & $0.0001^{* * *}$ \\
& Intertidal: inshore, offshore & 3.4196 & $0.0001^{* * *}$ \\
& Inshore: subtidal, intertidal & 5.9987 & $0.0001^{* * *}$ \\
$\begin{array}{l}\text { Shelf position (inshore) } x \\
\text { tidal zone (subtidal) }\end{array}$ & Offshore: subtidal, intertidal & 2.9701 & $0.0001^{* * *}$ \\
& Inshore South, Inshore Central & 2.5832 & $0.0001^{* * *}$ \\
& Inshore South, Inshore North & 1.2267 & $0.1911 n s$ \\
$\begin{array}{l}\text { Shelf position (inshore) } \\
\text { tidal zone (intertidal) }\end{array}$ & Inshore Central, Inshore North & 1.8092 & $0.0201 n s$ \\
& Inshore South, Inshore Central & 2.4787 & $0.0016^{*}$ \\
$\begin{array}{l}\text { Shelf position (offshore) } \\
\text { tidal zone (intertidal) }\end{array}$ & Inshore South, Inshore North & 1.5463 & $0.0713 n s$ \\
\hline
\end{tabular}

slight tendency for hard coral cover to be high on north-east exposures of individual reefs, although all reef aspects were not comprehensively surveyed.

Across all surveyed stations the highest mean coral cover was recorded on the mid-littoral reef platform at station $41 / \mathrm{K} 10$, Cassini Island $(76.00 \%$ $\pm 6.23 \%$ ). High coral cover was also recorded in subtidal habitats at station $83 /$ K11, Brue Reef $(73.67 \% \pm 7.06 \%)$; on the reef slope within the channel at 5/K09 Adele Island $(66.00 \% \pm 5.03 \%)$; on the slope at $69 / \mathrm{K} 11$ on an unnamed patchreef outcrop $(62.00 \% \pm 2.31 \%)$ and on the reef slope at $149 / \mathrm{K} 14$, Mermaid Reef $(56.00 \% \pm 0.10 \%)$. Intertidally, the station with the highest mean level of hard coral cover was station 163/K14 at Imperieuse Reef $(45.00 \% \pm 3.00 \%)$ followed by 21 / K09, Montgomery Reef $(42.00 \% \pm 0.00 \%)$; station $172 / K 14$, Clerke Reef $(37.00 \% \pm 10.00 \%)$ and at 3 / K09, Adele Island $(33.34 \% \pm 2.67 \%$ ) (Appendix 1).

\section{DISCUSSION}

This dataset consisting of 164 stations across 33 reef/island groups is the first region wide compilation of benthic community structure and composition data for the Kimberley marine wilderness area. It shows that the Kimberley reefs are heterogeneous and confirms the assumption that distinct offshore and inshore communities exist off the Kimberley coast (Wilson 2013; Richards et al. 2014). There are also clear distinctions between the intertidal and subtidal communities and spatial partitioning that reflects macro-scale environmental influences.

The major biotic components that structure reefs in the region are hard corals, turf algae and macroalgae. The offshore reefs have a higher coverage of turf algae, Halimeda spp., coralline algae and soft corals than the inshore reefs, but the inshore reefs have a higher coverage of hard corals, 

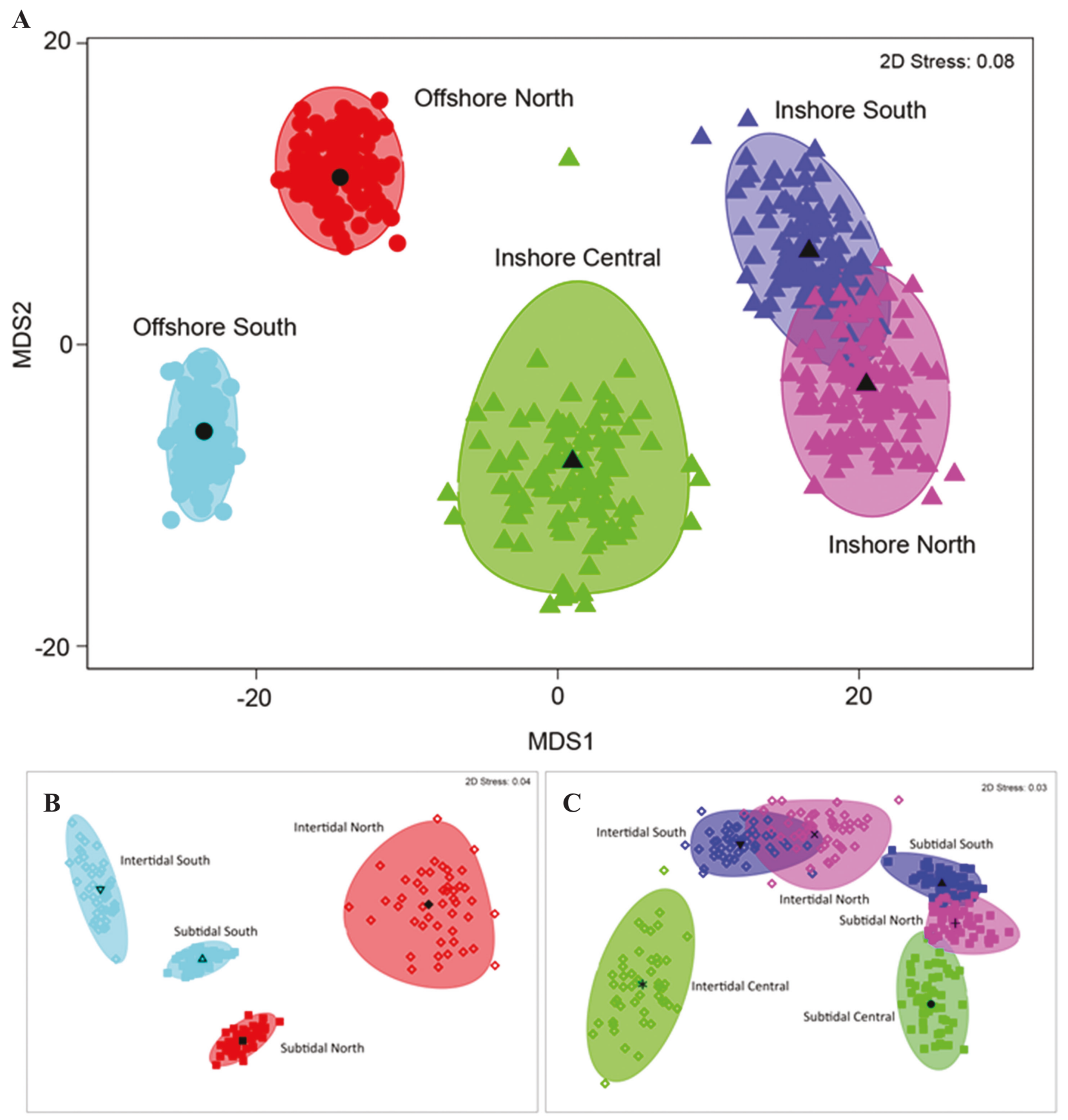

FIGURE $8 \quad$ Non-Metric multidimensional scale plot illustrating the 95\% confidence for A. subregions; B. offshore tidal zones, and; C. inshore tidal zones.

sponges and macroalgae. Subtidally, there is higher cover of hard corals, soft corals, sponges, Halimeda spp., coralline algae and other invertebrates, but intertidally there is a higher cover of turf algae, macroalgae and seagrasses. The highest level of macroalgal cover is found in inshore intertidal zones and the inshore subtidal zones have the highest level of hard coral cover. Soft corals reached their highest level of coverage in offshore subtidal zones, and sponges attained the highest level of cover in inshore subtidal regions. Such differences in community composition are not surprising given the distinctly different environmental settings experienced across the shelf and across depths (Thackway and Cresswell 1998; Wilson 2013; Bryce et al. 2017).

We did not measure environmental parameters in this study. However, benthic organisms living at the land-sea interface in the inshore Kimberley are governed by a daily macrotidal 

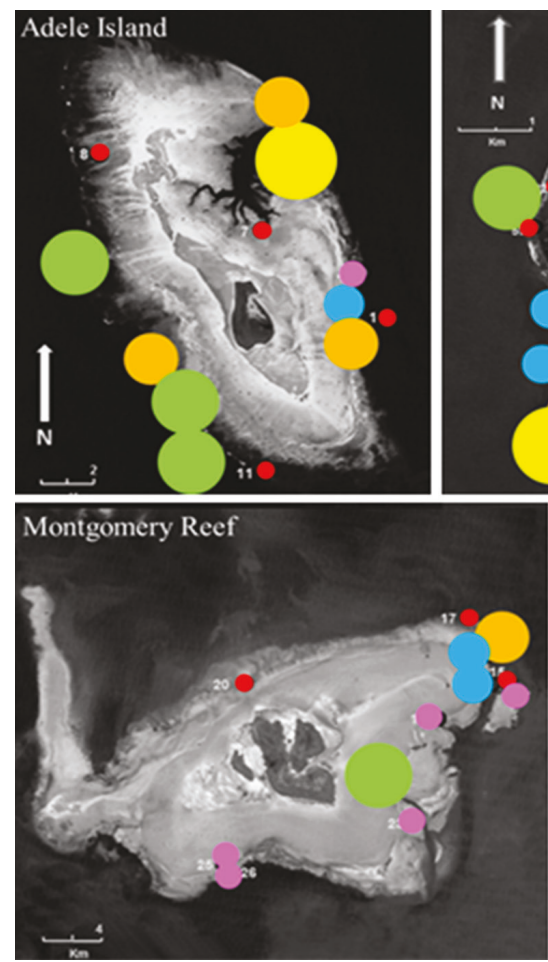
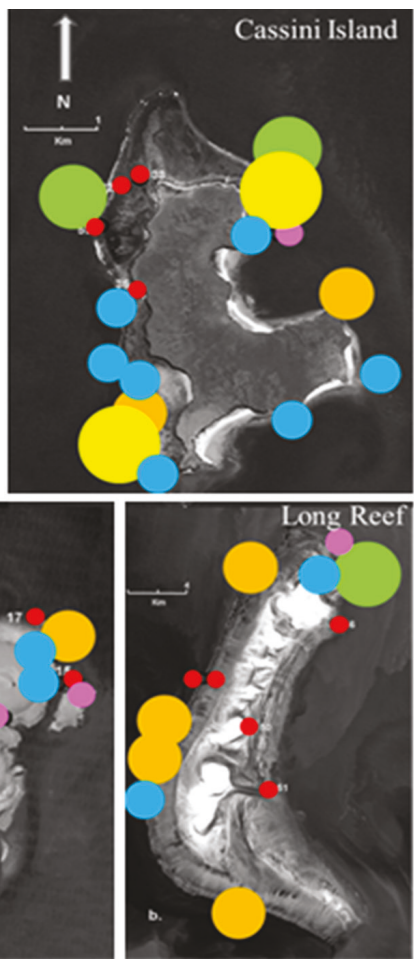
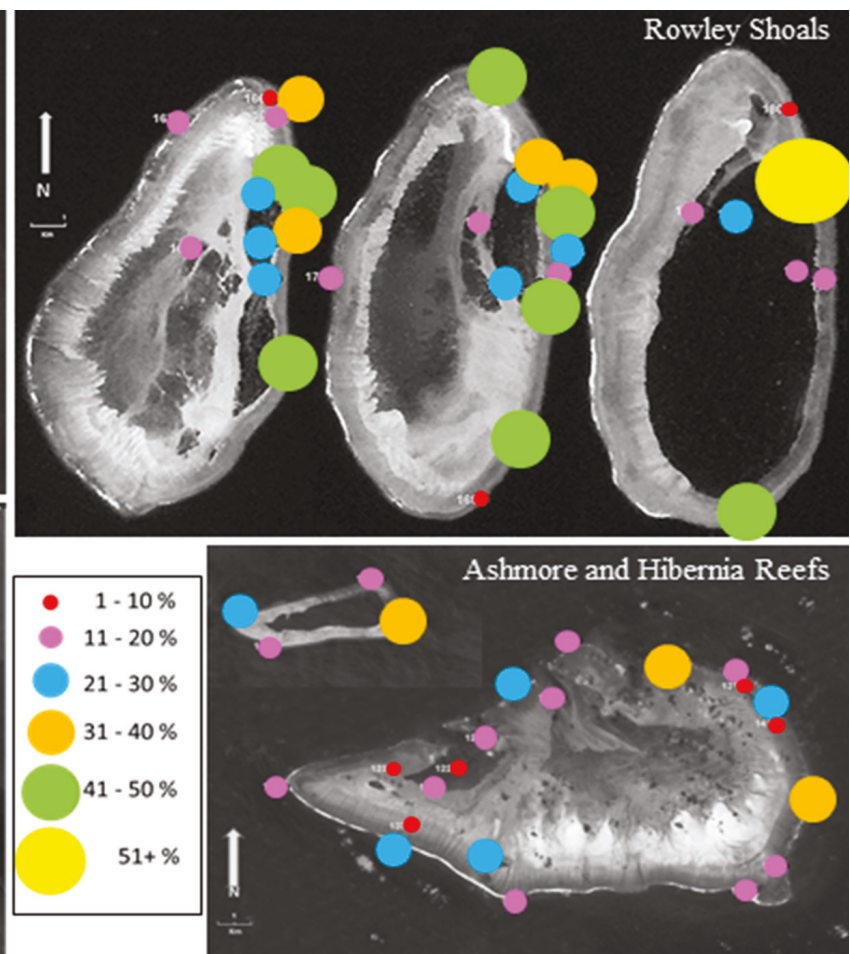

FIGURE 9 Mean percentage hard coral cover at the six reefs where multiple stations were surveyed.

cycle and a fortnightly neap-spring tidal cycle that sees tidal oscillations range in amplitude from 3-11 m (Thackway and Cresswell 1998). Intertidal communities must withstand multiple stressors including subaerial exposure at low tide, fluctuating and sometimes extreme temperature, sunlight and wind conditions and physical damage from waves and freshwater inundation (Glynn 1976; Le Tissier and Brown 1996; Dunne and Brown 2001). Despite extreme environmental conditions, previous studies have shown exceptionally diverse intertidal coral communities exist in the inshore Kimberly (Wilson et al. 2011; Richards et al. 2015). We show the mean level of hard coral cover on inshore intertidal reefs $(14.94 \% \pm 2.34 \%)$ is three times higher than an earlier estimate of intertidal hard coral cover $(<5 \%$ see Purcell 2002) and higher than the level of intertidal hard coral cover recorded offshore $(11.91 \% \pm 3.60 \%)$. While this finding may at first seem surprising, it most likely relates to the higher level of wave energy and subsequent scouring experienced by offshore reef systems, especially during cyclone and storm events (Fabricius et al. 2008). Compared to the exposed offshore locations, the 2500 islands along the inshore Kimberley would afford greater opportunities for protection.

The offshore and inshore habitats also differed in the level of suspended sediment. The offshore environment is best described as oligotrophic (Wilson 2013). While inshore monsoonal rainfall causes flooding of approximately 30 major rivers that drain into the shallow nearshore marine environment of the Sahul Shelf. During the wet season the large river systems of the region flood, transporting huge quantities of terrigenous sediment containing a high mineral clay composition into the nearshore environments (Gingele et al. 2001). These fine clay sediments are constantly mobilised, resuspended and deposited by tide-driven currents and strong prevailing winds across the reefs. Hence, it is not surprising that we found rock and silt to be the dominant abiotic groups inshore.

Traditional ecological theory asserts that photosynthetic animals prefer clear oligotrophic conditions and that sediment detrimentally affects the metabolism, reproductive behaviour and growth of benthic invertebrates such as corals (Loya 1976; Stafford-Smith and Ormond 1992; Reigl and Branch 1995; Gilmour 1999; Fabricius and Wolanski 2000; Humanes et al. 2017). However, more recently it has been hypothesised that in areas where there are naturally high levels of suspended sediments, such as the inshore Kimberley (Richards et al. 2015) and Great Barrier Reef (GBR; Morgan et al. 2017), suspended solids may protect photosynthetic benthos from solar radiation by lowering the 
intensity of down welling irradiance (Anthony et al. 2007; Devlin et al. 2008). Furthermore, the high load of organic nutrients may actually enhance the opportunities for heterotrophic feeding (Anthony 2000; Anthony and Fabricius 2000) and our finding of high levels of both hard coral and sponge cover in the inshore subtidal zone supports this premise for these taxa.

Our analysis supports the findings of others (Hooper 1994; Fromont and Vanderklift 2009) that the northern and southern offshore subregions are distinct from each other and should be treated as separate management units. In the southern subregion (Rowley Shoals), the mean level of hard coral cover $(27.92 \% \pm 2.52 \%)$ was higher than in the northern subregion (Ashmore and Hibernia Reefs, Browse Island, $17.26 \% \pm 5.57 \%$ ). However, the northern subregion was uniquely characterised by higher levels of cover of a variety of other taxa, including soft corals, Halimeda spp., seagrasses and other invertebrates (molluscs, anemones etc.). That soft corals are a prominent part of the reef community at Ashmore, Hibernia and Cartier Reefs has been alluded to in the past (Kospartov et al. 2006; Richards et al. 2009; Bryce and Sampey 2014). Similarly, based on historical records Ashmore and Hibernia Reefs appear to host far greater molluscan diversity than the Rowley Shoals (Willan et al. 2014). Hence, while Rowley Shoals is an important refuge for hard corals, Ashmore and surrounding reefs are important refuges for a wider diversity of benthic taxa.

Ashmore Reef is a Commonwealth Marine Reserve and the level of benthic cover at this location has been intermittently monitored over the last decade (Kospartov et al. 2006; Richards et al. 2009; Heyward et al. 2012) facilitating temporal comparisons. The mean level of hard coral cover recorded at the 22 stations surveyed at Ashmore Reef in $2013(14.9 \% \pm 2.12 \%$, excluding Hibernia and Browse Island) is lower than the mean level of coral cover recorded at eight sites in 2009 (29.4\% $\pm 1.83 \%$ ), but higher than the level recorded at the same sites in $2005(10.2 \% \pm 1.46 \%)$ (Ceccarelli et al. 2011). This level of hard coral cover is also lower than the levels recorded at the same eight sites in 2010 and $2011(24.36 \%-26.23 \%$, Heyward et al. 2012). For soft corals, the mean level of soft coral cover recorded in $2013(4.44 \% \pm 0.98 \%)$ is approximately half that recorded in $2009(8.3 \% \pm$ $1.4 \%)$ and similar to the level recorded in 2005 (4.5\% $\pm 0.63 \%$ ) (Ceccarelli et al. 2011). It is also lower than the levels recorded in 2010 and $2011(6.86 \% \pm 6.54 \%$, Heyward et al. 2012). Whether the observed decline in hard and soft coral cover between 2011 and 2013 represents biologically meaningful region wide declines or artifacts of sampling in different habitat zones (intertidal and $12 \mathrm{~m}$ in this survey versus 3-5 $\mathrm{m}$ and 8-10 $\mathrm{m}$ in Ceccarelli and Heyward) or methodological inconsistencies cannot be resolved at this point.

When comparing the offshore regions, the higher level of coral cover recorded at the Rowley Shoals is likely to relate Ashmore Reef experiencing at least two historical bleaching events (2003 and 2010, see Ceccarelli et al. 2012; Heyward et al. 2012), whilst only minor coral bleaching has been observed at the Rowley Shoals. The factors underpinning the observed resilience of the Rowley Shoals to previous thermal stress events are not well understood, but a recent comparative study of environmental conditions on south-east Indian Ocean reefs shows the Rowley Shoals is exposed to a wider range of temperature variation than the northern atolls (see Zinke et al. 2018) and this may in part explain the greater inherent thermo-tolerance of the Rowley Shoals system. Alternatively, favorable local conditions at the time of these events (cooler sea surface temperatures and increased wind and cloud) may have mitigated the stress.

Inshore, there were some interesting patterns of subregional differentiation. The Inshore Central was significantly different from both the Inshore North and Inshore South, yet these latter subregions were not significantly different from each other. The disparity is largely driven by latitudinal variation in the composition of floral communities, whose structure shifted from macroalgal domination in the north and south to turf algae and coralline algal domination in the Inshore Central. There are numerous possible explanations for this pattern. High macroalgae cover on tropical reefs can be indicative of low herbivore abundance (Przeslawski 2008; Hughes et al. 2010). However, herbivorous fishes are generally not targeted in the regions recreational or commercial fisheries, and the level of fishing for carnivorous fishes in the Kimberley is considered to be relatively low, hence overfishing is not a likely explanation for the abundance of macroalgae. Given the Kimberley waters have been described as some of the least productive waters for finfish in the world (Molony et al. 2011), it is possible there are naturally low levels of herbivore abundance or alternatively, high algal cover may be a natural phenomenon, but further research should be undertaken to substantiate this.

The higher level of macroalgal cover in the Inshore North and Inshore South may also reflect differing nutrient levels. Macroalgae such as Sargassum use particulate matter as a nutrient 
source (Schaffelke 1999); hence the finding of a higher level of macroalgal cover may indicate higher nutrient levels in those subregions (Huisman and Sampey 2014). However, further data are needed to test that hypothesis. Nevertheless, a high level of macroalgal cover may not be restrictive to the corals growing in the Kimberley because distinct patterns of zonation were apparent across the intertidal platforms (unpublished data). In the Kimberley, there is a tendency for macroalgae to dominate the upper littoral and hard corals to dominate the lower littoral and reef crest, hence both these important functional groups coexist, albeit partitioned, on a single narrow fringing-reef platform.

Coralline algae are commonly associated with high wave energy reef crest locations, and as expected reached the greatest levels of abundance offshore, but coralline algal terraces are also an important feature of the inshore reefs (Wilson and Blake 2011; Richards and O'Leary 2015; Solihuddin et al. 2015), with the highest level of coralline algae cover recorded in the Inshore Central. This may be another indicator that nutrient levels are lower in the central Kimberley, but could also be a result of other physical (e.g. temperature, light, currents, substrate); chemical (e.g. water chemistry, dissolved salts, gases), or biological factors (e.g. competition and grazing pressure) (Wray 2009). Overall, marine flora forms the foundation of the inshore Kimberley marine food web and play essential functional roles, such as habitat provision and reef consolidation (Huisman and Sampey 2014).

Region wide, the mean level of hard coral cover was $23.3 \%$ ( $31 \%$ in the subtidal and $14 \%$ in the intertidal zone), but the percent cover of hard coral varied dramatically between stations (e.g. 76\% was recorded at Cassini Island station 41/K10), and was dependent on tidal zonation (intertidal or subtidal), cross shelf placement (inshore or offshore) and the subregion (latitude). The regional mean reported here is slightly higher than the whole-ofreef average recorded on the GBR in 2004 (21.7\%, Sweatman et al. 2011), but lower than the average of $27 \%-33 \%$ reported in Osborne et al. (2011). However, it is very similar to the regional average reported from the entire Indo-Pacific in 2003 (22.1\%, Bruno and Selig 2007). Considering the Kimberley is a minimally impacted tropical reef ecosystem, the most relevant comparison is to the northern GBR. Based on surveys conducted from 1985-2012 the mean level of hard coral cover in the northern GBR was $\sim 35 \%$ (De'ath et al. 2014). However, this has dramatically declined following the 2016-2017 bleaching events with the latest estimates of hard coral cover in the two most northerly sectors of the GBR to be 10-20\% (AIMS $2017 \mathrm{a}, \mathrm{b}$ ).
It is worth noting the regional estimate of hard coral cover presented here is likely to be an underestimate because, unlike the sites chosen for long-term monitoring of the GBR, a variety of noncoral habitat was surveyed in the present study. These Kimberley surveys were undertaken as part of a wider multi-taxon biodiversity study, which necessitated surveying a diversity of habitat types. Furthermore, habitats where corals are known to dominate, such as the reef crest and upper slope, were not surveyed in this study and neither were numerous intertidal sites in the Bonaparte Archipelago and Buccaneer Archipelagos, which are renowned as hotspots for the diversity and abundance of hard corals (Wilson et al. 2011; Richards et al. 2015).

Previously there has been a shortage of quantitative baseline data concerning benthic communities for Kimberley marine environments (see Waples 2007). This study characterises benthic communities throughout the survey area highlighting similarities and differences in benthic composition across various habitat types and geographic locations. Although this dataset provides insight into the most dominant biotic and abiotic benthos occurring at each location, the stations were typically located either intertidally or at approximately $12 \mathrm{~m}$ depth and only serve as representatives of these habitats and zones. Some well-known seagrass habitats were not surveyed, for example the Sunday Island group (Walker 1995; Kendrick et al. 2016). Neither were other locations where coralline algae are known to dominate (Jalan Island, Richards and O'Leary 2015; Solihuddin et al. 2016), deeper reef zones where soft corals are likely to occur in greater abundance (Bryce et al. 2014), nearshore reefs, or reefs to the north of Cape Bougainville or south of Bathurst Island.

Similarly, it should be noted that this dataset does not represent seasonal change, as all surveys were conducted during September and October of each survey year (2009-2014). Macro-algae cover can fluctuate seasonally and so caution should be exercised when comparing algal percent cover from different seasons. Furthermore, coral communities are disturbance driven (e.g. cyclones and bleaching) and so coral populations are often in flux. As such, a single snapshot of coral cover is an inadequate representation of the health or resilience of a particular reef (Smith et al. 2016). Nevertheless, the data presented here offers a quantitative glimpse of the most common taxa and forms a critical reference dataset for future monitoring. Ongoing monitoring of reefs and across habitat zones is required to provide accurate health assessments of these communities. 
Overall we provide data to substantiate that the intertidal and subtidal habitats of the inshore and offshore Kimberley are significant parts of the Australian reefscape. Parts of the offshore reef ecosystems examined in this study receive either federal (Ashmore and Cartier National Marine Reserve) or state (Rowley Shoals Marine Protected Area) protection and parts of our inshore survey area fall within the Larang Garam (Camden Sound) Protected Area and North Kimberley Marine Park. Our data indicate that managing the subregions as defined here as discrete units is warranted. Given the Inshore Central and Inshore Northern subregions have distinctive biotic and abiotic characters, and that both of these subregions fall within the North Kimberley Marine Park planning area, further spatial planning may be warranted to ensure the diversity of benthic communities within this expansive management area is adequately represented within protected areas.

\section{ACKNOWLEDGEMENTS}

The Western Australian Museum and its partner agencies respectfully acknowledge the Traditional Custodians of the Kimberley land and sea country, of Elders past and present, and in particular the Dambimangari and Wunambal Gaambera peoples, for collections made on their sea country.

The authors would like to acknowledge Peter Morrison, Nick Thacke, Celeste Wilson, Monique Grol and Courtney Wood for data collection. We also thank Stacy Osborne who provided technical support for the photographic analysis and Kate Dawson for data processing. A special thank you to Andy Halford for assistance with the statistical analysis, and to George Shendrawi, Andrew Heyward and Glenn Moore for useful comments that helped to improve the manuscript. This project was funded by Woodside Energy and the Western Australian Museum through the Woodside Collection Project (Kimberley). Dr Richards was also supported in the write-up stages by a Curtin University Research Fellowship.

\section{REFERENCES}

Australian Institute of Marine Science (2017a). Report on surveys of the Cape Grenville sector of the Great Barrier Reef. https://www.aims.gov.au/reef-monitoring/capegrenville-sector-2017.

Australian Institute of Marine Science (2017b). Report on surveys of the Princess Charlotte Bay sector of the Great Barrier Reef. https://www.aims.gov.au/reef-monitoring/ princess-charlotte-bay-sector-2017.

Anthony, K.R.N. (2000). Enhanced particle feeding capacity of corals on turbid reefs (Great Barrier Reef). Coral Reefs 19: 50-67.
Anthony, K.R.N. and Fabricius, K. (2000). Shifting roles of heterotrophy and autotrophy in coral energetics under varying turbidity. Journal of Experimental Marine Biology and Ecology 252: 221-253.

Anthony K.R.N., Connolly, S.R. and Hoegh-Guldberg, O. (2007). Bleaching, energetics, and coral mortality risk: Effects of temperature, light, and sediment regime. Limnology and Oceanography 52: 716-726.

Ateweberhan, M., McClanahan, T.R., Graham, N.A.J. and Sheppard, C.R.C. (2011). Episodic heterogenous decline and recovery of coral cover in the Indian Ocean. Coral Reefs 30: 739-752.

Arias-Gonzàlez, J.E., Núñez-Lara, E., RodríguezZaragoza, F.A. and Legendre, P. (2011). Reefscape proxies for the conservation of Caribbean coral reef biodiversity. Ciencias Marinas 37: 87-96.

Baum, G., Januar, I., Ferse, S.C.A., Wild, C. and Kunzmann, A. (2016). Abundance and physiology of dominant soft coral linked to water quality in Jakarta Bay, Indonesia. PeerJ 4: e2625.

Bell, J.D. and Galzin, R. (1984). Influence of live coral cover on coral-reef fish communities. Marine Ecology Progress Series 15: 265-274.

Bruno, J.F., Selig, E.R., Casey, K.S., Page, C.A., Willis, B.L., Harvell, C.D., Sweatman, H. and Melendy, A.M. (2007). Thermal stress and coral cover as drivers of coral disease outbreaks. PLoS Biology 5: e124.

Bruno, J.F. and Selig, E.R. (2007). Regional decline of coral cover in the Indo-Pacific: timing, extent, and subregional comparisons. PLoS ONE 2: e711.

Bryce, C., Bryce, M. and Radford, B.T. (2017). Kimberley marine biota. Survey data: project methods and station geomorphology. Records of the Western Australian Museum Supplement 85: 1-43.

Bryce, M. and Sampey, A. (2014). Kimberley marine biota. Historical data: soft corals and sea fans (Octocorallia). Records of the Western Australian Museum Supplement 84: 101-110.

Butt, N., Beyer, H.L., Bennett, J.R., Biggs, D., Maggini, R., Mills, M., Renwick, A.R., Seabrook, L.M. and Possingham, H.P. (2013). Biodiversity Risks from Fossil Fuel Extraction. Science 342: 425-426.

Ceccarelli, D.M., Richards, Z.T., Pratchett, M.S. and Cvitanovic, C. (2011). Rapid increase in coral cover on an isolated coral reef, the Ashmore Reef National Nature Reserve, north-western Australia. Marine and Freshwater Research 62: 1214-1220.

Cheal, A.J., MacNeil, M.A., Cripps, E., Emslie, M.J., Jonker, M., Schaffelke, B. and Sweatman, H. (2010). Coral-macroalgal phase shifts or reef resilience: links with diversity and functional roles of herbivorous fishes on the Great Barrier Reef. Coral Reefs 29: 10051015.

Clarke, K.R and Gorley, R.N. (2015). PRIMER v7: User Manual/Tutorial. PRIMER-E. Plymouth, United Kingdom.

De'ath, G., Fabricius, K.E., Sweatman, H. and Puotinen, M. (2012). The 27 year decline of coral cover on the Great Barrier Reef and its causes. Proceedings of the National Academy of Sciences 109: 17995-17999.

Department of Environment and Conservation (2009). Protecting the Kimberley - A synthesis of scientific knowledge to support conservation management in the Kimberley region of Western Australia. Perth, Western Australia: http:/ /imos.org.au/fileadmin/user_upload/ shared/IMOS\%20General/documents / external_ reports/2009224_kimberleysciencerpt_finalweb_2_.pdf 
Diaz-Pulido, G., McCook, L.J., Dove, S., Berkelmans, R., Roff, G., Kline, D.I., Weeks, S., Evans, R.D., Williamson, D.H. and Hoegh-Guldberg, O. (2009). Doom and boom on a resilient reef: climate change, algal overgrowth and coral recovery. PLOS ONE 4: p.e5239.

Dornelas, M., Gotelli, N.J., McGill, B., Shimadzu, H., Moyes, F., Sievers, C. and Magurran, A.E. (2014). Assemblage time series reveal biodiversity change but not systematic loss. Science 344: 296-299.

Dunne, R.P. and Brown, B.E. (2001). The influence of solar radiation on bleaching of shallow water reef corals in the Andaman Sea, 1993-1998. Coral Reefs 20: 201-210.

Fabricius, K.E. and Wolanski, E. (2000). Rapid smothering of coral reef organisms by muddy marine snow. Estuarine and Coastal Shelf Science 50: 115-120.

Fabricius, K.E., De'arth, G., Puotinen, M.L. Done, T., Cooper, T.F. and Burgess S.C. (2008). Disturbance gradients on inshore and offshore coral reefs caused by a severe tropical cyclone. Limnology and Oceanography 53: 690-704.

Fox, J.J. (1998). Reefs and shoals in Australia - Indonesian relations: traditional Indonesian fishermen. 1998. In: Milner, A. and Quilty, M. (eds) Australia in Asia: Episodes. Oxford University Press, Melbourne, Victoria: 111-139.

Fromont, J. and Vanderklift, M.A. (2009). Porifera (sponges) of Mermaid, Scott and Seringapatam Reefs, north Western Australia. Records of the Western Australian Museum Supplement 77: 89-103.

Gibson, R., Atkinson, R., Gordon, J., Smith, I. and Hughes, D. (2011). Coral-associated invertebrates: diversity, ecological importance and vulnerability to disturbance. Oceanography and Marine Biology: An Annual Review 49: 43-104.

Gilmour, J. (1999). Experimental investigation into the effects of suspended sediment on fertilisation, larval survival and settlement in a scleractinian coral. Marine Biology 135: 451-462.

Gilmour, J.P., Smith, L.D., Heyward, A.J., Baird, A.H. and Pratchett, M.S. (2013). Recovery of an isolated coral reef system following severe disturbance. Science 340 : 69-71.

Glynn, P.W. (1976). Some physical and biological determinants of coral community structure in the eastern Pacific. Ecological Monographs 46: 431-456.

Graham, N.A.J., Chong-Seng, K.M., Huchery, C., Januchowski-Hartley, F.A. and Nash, K.L. (2014). Coral reef community composition in the context of disturbance history on the Great Barrier Reef, Australia. PLOS ONE 9: e101204.

Halpern, B.S., Walbridge, S., Selkoe, K.A., Kappel, C.V., Micheli, F., D'Agrosa, C., Bruno, J.F., Casey, K.S., Ebert, C. and Fox, H.E. (2008). A global map of human impact on marine ecosystems. Science 319: 948-952.

Heyward, A., Jones, R., Travers, M., Burns, K., Suosaari, G., Colquhoun, J., Case, M., Radford, B., Meekan, M., Markey, K. and Schenk, T. (2011). Montara: 2011 Shallow Reef Surveys at Ashmore, Cartier and Seringapatam Reefs. Final Report for PTTEP Australasia (Ashmore Cartier) Pty. Ltd. Australian Institute of Marine Science, Townsville, Queensland.

Hooper, J.N.A. (1994). Coral reef sponges of the Sahul shelf - a case for habitat preservation. Memoirs of the Queensland Museum 36: 93-106.

Hill, J. and Wilkinson, C. (2004). Methods for ecological monitoring of coral reefs. Australian Institute of Marine Science: Townsville, Queensland.
Hughes, T.P., Rodrigues, M.J., Bellwood, D.R., Ceccarelli, D., Hoegh-Guldberg, O., McCook, L., Moltschaniwskyj, N., Pratchett, M.S., Steneck, R.S. and Willis, B. (2007). Phase shifts, herbivory, and the resilience of coral reefs to climate change. Current Biology 17: 360-365.

Hughes, T.P., Graham, N.A.J., Jackson, J.B.C., Mumby, P.J. and Steneck, R.S. (2010). Rising to the challenge of sustaining coral reef resilience. Trends in Ecology and Evolution 25: 633-642.

Hughes, T.P., Kerry, J.T., Álvarez-Noriega, M., ÁlvarezRomero, J.G., Anderson, K.D., Baird, A.H., Babcock, R.C., Beger, M., Bellwood, D.R., Berkelmans, R. and Bridge, T.C. (2017). Global warming and recurrent mass bleaching of corals. Nature 543: 373-377.

Huisman, J.A. and Sampey, A. (2014). Kimberley marine biota. Historical data: marine plants. Records of The Western Australian Museum Supplement 84: 45-67.

Humanes, A., Ricardo, G.F., Willis, B.L., Fabricius K.E. and Negri A.P. (2017). Cumulative effects of suspended sediments, organic nutrients and temperatures stress on early life history stages of the coral Acropora tenuis. Scientific Reports 4: 1-11.

Ivey, G., Brinkman, R., Lowe, R., Jones, N., Symonds, G. and Espinosa-Gayosso, A. (2016). Physical oceanographic dynamics in the Kimberley. Report of Project 2.2.1 prepared for the Kimberley Marine Research Program, Western Australian Marine Science Institution, Perth, Western Australia.

Jackson, J.B., Kirby, M.X., Berger, W.H., Bjorndal, K.A., Botsford, L.W., Bourque, B.J., Bradbury, R.H., Cooke, R., Erlandson, J., Estes, J.A. and Hughes, T.P. (2001). Historical overfishing and the recent collapse of coastal ecosystems. Science 293: 629-637.

Jackson, J.B. (2001). What was natural in the coastal oceans? Proceedings of the National Academy of Sciences 98: 5411-5418.

Jokiel, P.L., Rodgers, K.S., Brown, E.K., Kenyon, J.C., Aeby, G., Smith, W.R. and Farrell, F. (2015). Comparison of methods used to estimate coral cover in the Hawaiian Islands. PeerJ 3: p.e954.

Jones, G.P., McCormick, M.I., Srinivasan, M. and Eagle, J.V. (2004). Coral decline threatens fish biodiversity in marine reserves. Proceedings of the National Academy of Sciences 101: 8251-8253.

Kark, S., Brokovich, E., Mazor, T. and Levin, N. (2015). Emerging conservation challenges and prospects in an era of offshore hydrocarbon exploration and exploitation. Conservation Biology 29: 1573-1585.

Kendrick, G.A., Vanderklift, M., Bearham, D., Mclaughlin, J., Greenwood, J., Säwström, C., Laverock, B., Chovrelat, L., Zavala-Perez, A., De Wever, L., Trapon, M., Grol, M., Guilbault, E., Oades, D., McCarthy, P., George, K., Sampi, T., George, D., Sampi, C., Edgar, Z., Dougal, K. and Howard, A. (2016). Benthic primary productivity: production and herbivory of seagrasses, macroalgae and microalgae. Report of 2.2.4 prepared for the Kimberley Marine Research Program, Western Australian Marine Science Institution, Perth, Western Australia.

Kohler, K.E. and Gill, S.M. (2006). Coral Point Count with Excel extensions (CPCe): A Visual Basic program for the determination of coral and substrate coverage using random point count methodology. Computers and Geosciences 32: 1259-1269.

Komyakova, V., Munday, P.L. and Jones, G.P. (2013). Relative importance of coral cover, habitat complexity 
and diversity in determining the structure of reef fish communities. PLoS ONE 8: e83178.

Knowlton, N. and Jackson, J.B. (2008). Shifting baselines, local impacts, and global change on coral reefs. PLoS Biology 6: e54.

Kospartov, M., Beger, M., Ceccarelli, D., Richards, Z. (2006). An assessment of the distrbiution and abundance of sea cucmbers, trochus, giant clams, coral, fish and invasive marine species at Ashmore Reef National Nature Reserve and Cartier Island Marine Reserve, 2005. Report for Department of the Environment and Heritage, Marine Protected Areas Management.

Le Tissier, M.D.A. and Brown, B.E. (1996). Dynamics of solar bleaching in the intertidal reef coral Goniastrea aspera at Ko Phuket, Thailand. Marine Ecology Progress Series 136: 235-244.

Loya, Y. (1976). Effects of water turbidity and sedimentation on the community structure of Puerto Rican corals. Bulletin of Marine Science 26: 450-466.

Magurran, A.E., Dornelas, M., Moyes, F., Gotelli, N.J. and McGill, B. (2015). Rapid biotic homogenization of marine fish assemblages. Nature Communications 6: 8405.

Molony, B.W., Newman, S.J., Joll, L., Lenanton, R.C.J. and Wise, B. (2011). Are Western Australian waters the least productive waters for finfish across two oceans? A review with a focus on finfish resources in the Kimberley region and north coast subregion. Journal of the Royal Society of Western Australia 94: 323-332.

Moore, C.H., Radford, B., Possingham, H., Heyward, A., Stewart, R., Watts, M., Prescott, J., Newman, S., Harvey, E., Fisher, R., Bryce, C., Lowe, R., Berry, O., Espinosa-Gayosso, A., Spore, E. and Saunders, T. (2016). Improving spatial prioritisation for remote marine regions: optimising biodiversity conservation and sustainable development trade-offs. Scientific Reports 6: 32029.

Morgan, K.M., Perry, C.T., Johnson, J.A. and Smithers, S.G. (2017). Nearshore turbid-zone corals exhibit high bleaching tolerance on the Great Barrier Reef following the 2016 ocean warming event. Frontiers in Marine Science 4: 224.

Le Nohaïc, M., Ross, C.L., Cornwall, C.E., Comeau, S., Lowe, R., McCulloch, M.T. and Schoepf, V. (2017). Marine heatwave causes unprecedented regional mass bleaching of thermally resistant corals in northwestern Australia. Scientific Reports 7: 14999.

Li, X., Ge, L., Hu, Z. and Chang, H.C. (2010). The 2009 Montara oil spill in the Timor Sea as observed by earth observation satellites. University of New South Wales, Australia.

Osborne, K., Dolman, A.M., Burgess S.C. and Johns, K.A. (2011). Disturbance and the Dynamics of Coral Cover on the Great Barrier Reef (1995-2009). PLOS ONE 6: e17516.

Przeslawski, R. Ahyong, S., Byrne, M, Wörheide, G. and Hutchins, P. (2008). Beyond corals and fish: The effects of climate change on noncoral benthic invertebrates of tropical reefs. Global Change Biology 14: 2773-2795.

Purcell, S.P. (2002). Intertidal reefs under extreme tidal flux in Buccaneer Archipelago, Western Australia. Coral Reefs 21: 191-192.

Richards, Z.T., Bryce, M. and Bryce, C. (2013). New records of atypical coral reef habitat in the Kimberley, Australia. Journal of Marine Biology 2013: 363894.

Richards, Z., Sampey, A. and Marsh, L. (2014). Kimberley marine biota. Historical data: scleractinian corals.
Records of the Western Australian Museum Supplement 84: 111-132.

Richards, Z.T. and O'Leary, M.J. (2015). The coralline algal cascades of Tallon Island (Jalan) fringing reef, NW Australia. Coral Reefs 34: 595.

Richards, Z.T., Garcia, R.A., Wallace, C.C., Rosser, N.L. and Muir, P. R. (2015). A diverse assemblage of reef corals thriving in a dynamic intertidal reef setting (Bonaparte Archipelago, Kimberley, Australia). PLoS ONE 10: e0117791.

Sampey, A., Bryce, C., Osborne, S. and Miles, A. (2014). Kimberley marine biota. Historical data: introduction and methods. Records of the Western Australian Museum Supplement 84: 19-43.

Sandin, S.A., Smith, J.E., DeMartini, E.E., Dinsdale, E.A., Donner, S.D., Friedlander, A.M., Konotchick, T., Malay, M., Maragos, J.E., Obura, D. and Pantos, O. (2008). Baselines and degradation of coral reefs in the northern Line Islands. PLoS ONE 3: e1548.

Schaffelke, B. (1999). Particulate organic matter as an alternative nutrient source for tropical Sargassum species (Fucales, Phaeophyceae). Journal of Phycology 35: 1150-1157.

Schoepf, V., Stat, M., Falter, J.L. and McCulloch, M.T. (2015). Limits to the thermal tolerance of corals adapted to a highly fluctuating, naturally extreme temperature environment. Scientific Reports 5: 17639.

Smith, L., Gilmour, J.P. and Heyward, A.J. (2008). Resilience of coral communities on an isolated system of reefs following catastrophic mass-bleaching. Coral Reefs 27: 197-205.

Smith, J.E., Brainard, R., Carter, A., Grillo, S., Edwards, C., Harris, J., Lewis, L. Obura, D., Rohwer, F., Sala, E., Vroom, P.S. and Sandin, S. (2016). Re-evaluating the health of coral reef communities: baselines and evidence for human impacts across the central Pacific. Proceedings of the Royal Society B 283: 20151985.

Solihuddin, T., Collins, L.B., Blakeway, D. and O'Leary, M.J. (2015). Holocene coral reef growth and sea level in a macrotidal, high turbidity setting: Cockatoo Island, Kimberley Bioregion, northwest Australia. Marine Geology 359: 50-60.

Solihuddin, T., O'Leary, M.J., Blakeway, D., Parnum, I., Kordi, M. and Collins, L.B. (2016). Holocene reef evolution in a macrotidal setting: Buccaneer Archipelago, Kimberley Bioregion, northwest Australia. Coral Reefs 25: 783-794.

Stafford-Smith, M.G. and Ormond, R.F.G. (1992). Sediment rejection mechanisms of 42 scleractinian corals. Australian Journal of Marine and Freshwater Sciences 43: 638-705.

Sweatman, H., Cheal, A., Coleman, G., Emslie, M., Jonker, M., Miller, I. and Osborne, K. (2008). Long-term monitoring of the Great Barrier Reef. Status Report no. 8. Australian Institute of Marine Science: Townsville, Queensland.

Sweatman, H., Delean, S. and Syms, C. (2011). Assessing loss of coral cover on Australia's Great Barrier Reef over two decades, with implication for longer-term trends. Coral Reefs 30: 521-531.

Teichert, C. and Fairbridge, R.W. (1948). Some coral reefs of the Sahul Shelf. Geographic Review 28: 222-249.

Thackway, R. and Cresswell, I.D. (1998). Interim marine and coastal regionalisation for Australian ecosystem based classification for marine and coastal environments. Environment Australia, Commonwealth Department of Environment: Canberra. 
van Hooidonk, R., Maynard, J., Tamelander, J., Gove, J., Ahmadia, G., Raymundo, L., Williams, G., Heron, S.F. and Planes, S. (2016). Local-scale projections of coral reef futures and implications of the Paris Agreement. Scientific Reports 6: 39666.

Walker, D.I. (1995). Survey of the marine biota of the southern Kimberley Islands, Western Australia. Part 5. Seagrasses and Macroalgae: 58-66. Western Australian Museum: Perth. Unpublished report.

Waples, K. (2007). Kimberley Biodiversity Review. EPA Services Unit and the Environmental Management Branch, Department of Environment and Conservation: Perth, Western Australia.

Watson, J.E., Joseph, L.N. and Watson, A.W. (2009). A rapid assessment of the impacts of the Montara oil leak on birds, cetaceans and marine reptiles. Spatial Ecology Laboratory.

Wilkinson, C.R. (2008). Status of coral reefs of the world: 2008. Australian Institute of Marine Science: Townsville, Queensland.

Wilson, B., Blake, S., Ryan, D. and Hacker, J. (2011). Reconnaissance of species-rich coral reefs in a muddy, macro-tidal, enclosed embayment, Talbot Bay, Kimberley, Western Australia. Journal of the Royal Society of Western Australia 94: 251-265.

Wilson, B.R. and Blake, S. (2011). Notes on the origin and biogeomorphology of Montgomery Reef, Kimberley, Western Australia. Journal of the Royal Society of Western Australia 94: 107-119.

Wilson, B.R. (2013). The biogeography of the Australian North West Shelf. Elsevier: Waltham, U.S.A.

Wilson, B.R. (2014). Kimberley marine biota. History and environment. Records of the Western Australian Museum Supplement 89: 1-18.

Wray, J.L. (2009). Calcareous algae (Vol. 4). Elsevier: Waltham, U.S.A.

Zinke, J., Gilmour, J.P., Fisher, R., Puotinen, M., Maina, J., Darling, E., Stat, M., Richards, Z.T., McClanahan, T.R., Beger, M. and Moore, C. (2018). Gradients of disturbance and environmental conditions shape coral community structure for south-eastern Indian Ocean reefs. Diversity and Distributions. DOI: 10.1111/ ddi. 12714 


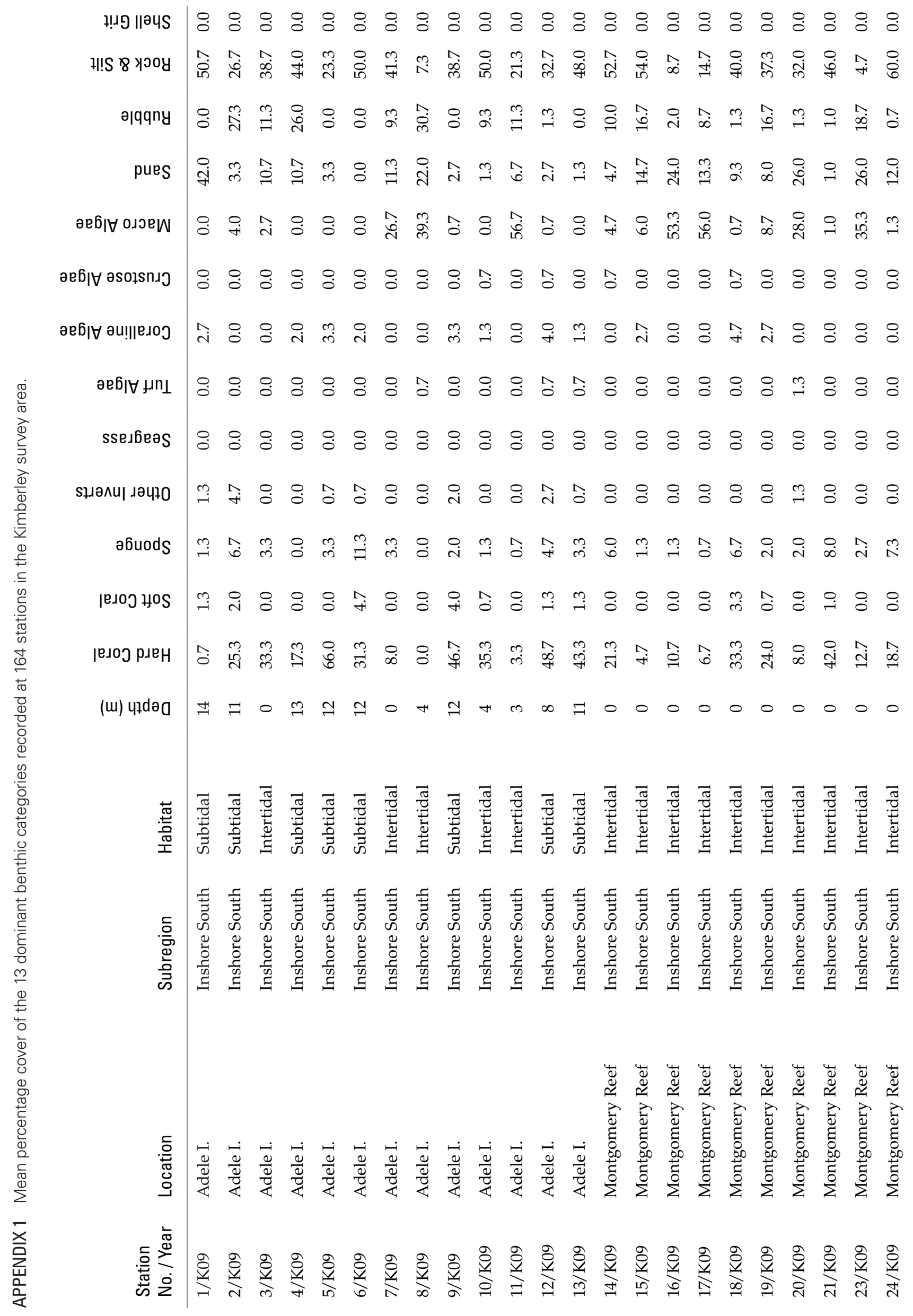




\begin{tabular}{|c|c|c|c|c|c|c|c|c|c|c|c|c|c|c|c|c|c|c|c|c|c|c|c|c|c|}
\hline |גן & $\stackrel{0}{0}$ & $\stackrel{0}{0}$ & : & $\stackrel{0}{\circ}$ & $\stackrel{0}{0}$ & $\ddot{\circ}$ & $\stackrel{\circ}{\circ}$ & $\stackrel{\circ}{\circ}$ & 0 & c & $\dot{s}$ & 8 & $\ddot{0}$ & $\stackrel{0}{0}$ & 0 & 0 & 0 & 0 & & & & 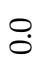 & $\dot{0}$ & $\circ$ & 0 \\
\hline HI!S \& ఖ & તิ & $\stackrel{\circ}{\stackrel{\infty}{\rightarrow}}$ & $\stackrel{+}{+}$ & $\stackrel{m}{\vec{\lambda}}$ & in & กิ & $\stackrel{\circ}{+}$ & $\hat{i}$ & הี & & & กิ & $\overrightarrow{6}$ & ले & $\infty$ & ๑ & $\exists$ & & & & & 0 & & & İ \\
\hline ә|qqny & 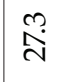 & $\ddot{m}$ & $\widehat{\mathrm{I}}$ & 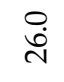 & 8 & $\stackrel{8}{\circ}$ & తి & $\stackrel{\sim}{\infty}$ & 8 & & & 8 & 0 & $\widehat{i}$ & ij & $\stackrel{\text { בִ }}{\exists}$ & bo & & & & & $\bar{c}$ & & & $\stackrel{\circ}{+}$ \\
\hline pues & $\widehat{\mathrm{A}}$ & $\stackrel{\circ}{\stackrel{H}{+}}$ & 官 & $\stackrel{m}{\stackrel{m}{\rightarrow}}$ & $\hat{o}$ & $\stackrel{8}{\circ}$ & $\stackrel{m}{a}$ & ત્త & r & & & f & $\stackrel{m}{\rightarrow}$ & $\stackrel{8}{\circ}$ & 8 & نُّن & $\begin{array}{c}m \\
m\end{array}$ & & & & & : & ஜ & & $\infty$ \\
\hline әеб|ఈ оцэеW & $\stackrel{m}{\stackrel{\theta}{n}}$ & $\stackrel{\circ}{+}$ & $\stackrel{\circ}{\circ}$ & $\stackrel{\circ}{\circ}$ & $\stackrel{\circ}{\circ}$ & $\stackrel{\circ}{\circ}$ & $\stackrel{0}{8}$ & $\stackrel{m}{\stackrel{\leftrightarrow}{f}}$ & $\stackrel{\circ}{\circ}$ & & & $\stackrel{8}{\circ}$ & $\stackrel{m}{\rightarrow}$ & $\hat{0}$ & $\stackrel{\circ}{\circ}$ & $\stackrel{\circ}{\circ}$ & $g$ & & & & & 8ิ & & & Oீ \\
\hline әеб|ఈ әsołsnגว & $\stackrel{0}{0}$ & $\stackrel{0}{0}$ & $\stackrel{\circ}{\circ}$ & $\stackrel{0}{\circ}$ & $\stackrel{0}{\circ}$ & $\stackrel{0}{0}$ & $\stackrel{0}{0}$ & $\stackrel{\circ}{\circ}$ & ㅇ. & & & $\stackrel{0}{\circ}$ & $\stackrel{0}{0}$ & $\stackrel{\circ}{\circ}$ & : & $\overbrace{0}^{\circ}$ & & 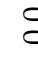 & & & & 0 & : & $\stackrel{0}{\circ}$ & $\stackrel{0}{\circ}$ \\
\hline әеб|Ұ әи!||едоэ & 8 & 8 & 8 & $\stackrel{0}{\circ}$ & 8 & $\widehat{\circ}$ & 8 & 8 & $\stackrel{\circ}{\circ}$ & & & $\stackrel{2}{n}$ & $\hat{o}$ & 8 & $\stackrel{\circ}{\circ}$ & ஜ & 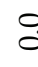 & 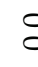 & & تُ & 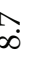 & $\dot{E}$ & 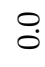 & 8 & $\stackrel{i}{i}$ \\
\hline әеб|甘 & $\stackrel{8}{0}$ & $\stackrel{8}{\circ}$ & $\stackrel{8}{\circ}$ & $\stackrel{8}{\circ}$ & 8 & $\stackrel{0}{\circ}$ & $\stackrel{0}{\circ}$ & $\stackrel{\circ}{\circ}$ & : & & & 8 & $\stackrel{0}{\circ}$ & $\stackrel{8}{\circ}$ & 8 & $\stackrel{\circ}{\circ}$ & ¿ & c & & ? & & ○. & : & $\circ$ & $\stackrel{0}{\circ}$ \\
\hline ssedfeəs & $\stackrel{0}{0}$ & $\stackrel{0}{0}$ & $\stackrel{\circ}{\circ}$ & $\stackrel{0}{\circ}$ & $\stackrel{0}{\circ}$ & $\stackrel{0}{0}$ & $\stackrel{0}{0}$ & $\stackrel{\circ}{\circ}$ & 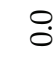 & & & $\stackrel{0}{0}$ & $\because$ & $\stackrel{0}{0}$ & : & 8 & & 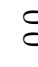 & & & & 0 & مُج & P. & : \\
\hline sцәли| дәчғ0 & $\stackrel{0}{0}$ & $\stackrel{\circ}{\circ}$ & $\stackrel{\circ}{\circ}$ & $\stackrel{\circ}{\circ}$ & $\stackrel{\circ}{\circ}$ & $\stackrel{0}{\circ}$ & $\stackrel{\circ}{\circ}$ & $\stackrel{\circ}{\circ}$ & 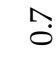 & & & $\stackrel{\circ}{\circ}$ & $\stackrel{0}{\circ}$ & $\stackrel{\circ}{\circ}$ & ن. & 5 & & & & ?: & & 0 & : & $\stackrel{\circ}{\circ}$ & $\stackrel{\circ}{\circ}$ \\
\hline əbuods & $\stackrel{n}{\rightarrow}$ & $\hat{o}$ & ๑ & $\stackrel{?}{\wedge}$ & $\stackrel{\circ}{+}$ & $\stackrel{\curvearrowright}{+}$ & $\stackrel{m}{\infty}$ & $\stackrel{\circ}{\circ}$ & 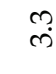 & & & i & $\stackrel{\circ}{i}$ & $\stackrel{0}{\circ}$ & $P_{\mathrm{i}}$ & fi & @ & & & & & $\stackrel{m}{\rightarrow}$ & 0 & $\widehat{o}$ & فำ \\
\hline ןеגоЈ НОS & : & $\hat{i}$ & $\stackrel{m}{m}$ & $\hat{\mathrm{i}}$ & $\hat{\sigma}$ & $\stackrel{0}{0}$ & : & $\stackrel{0}{\circ}$ & ते & & & $\stackrel{m}{m}$ & $\stackrel{m}{\rightarrow}$ & $\stackrel{0}{0}$ & ji & Fi & $E$ & $c$ & & جִ & & $\stackrel{\circ}{\circ}$ & i & & $\stackrel{0}{\circ}$ \\
\hline ןедоэ рлен & $\widehat{\mathrm{I}}$ & $\stackrel{?}{\stackrel{a}{a}}$ & $\stackrel{\circ}{\text { ì }}$ & nें & $\stackrel{\hat{\infty}}{\infty}$ & ¿̊ं & $\hat{o}$ & $\stackrel{m}{m}$ & F & & & की & $\stackrel{m}{\vec{N}}$ & तु & ำ & ิิ & $c$ & & & & & $\widehat{\sigma}$ & $\stackrel{\sim}{0}$ & i & $\stackrel{i}{i}$ \\
\hline (m) чłdəح & 0 & 0 & $\underset{7}{7}$ & $\stackrel{m}{-1}$ & $F$ & 요 & 0 & $N$ & $\approx$ & 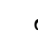 & 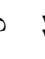 & $\exists$ & $\infty$ & H & $F$ & 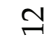 & 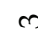 & c & & & & 0 & & & 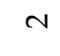 \\
\hline 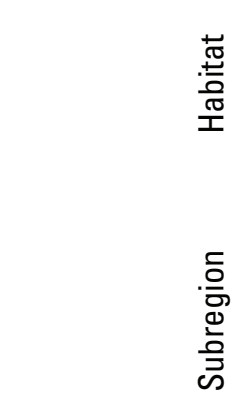 & 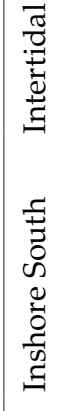 & 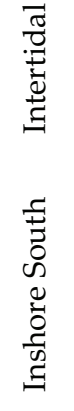 & 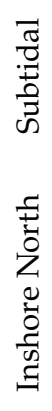 & 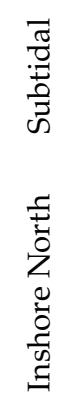 & 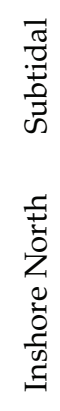 & 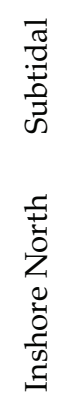 & 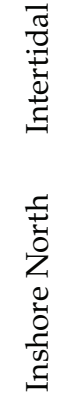 & 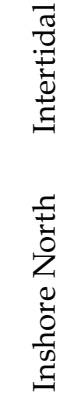 & 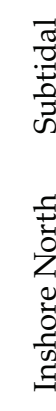 & 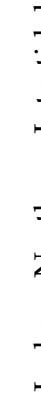 & 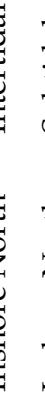 & 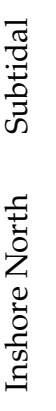 & 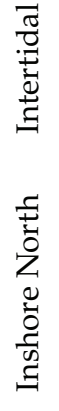 & 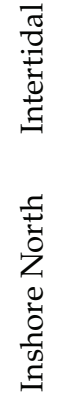 & 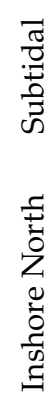 & 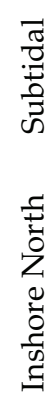 & 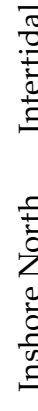 & 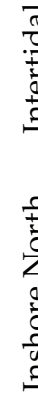 & & 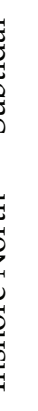 & 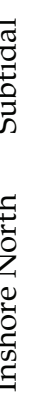 & 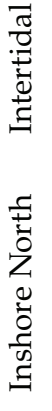 & 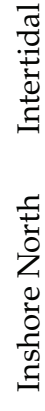 & 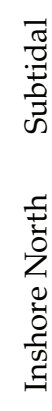 & 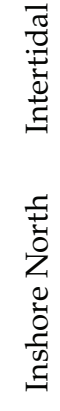 \\
\hline 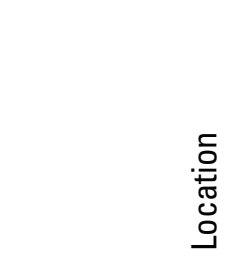 & 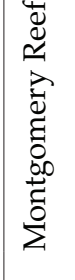 & 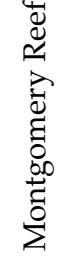 & 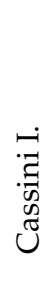 & $\begin{array}{l}\overrightarrow{\vec{J}} \\
\tilde{W} \\
\tilde{U}\end{array}$ & $\begin{array}{l}-\vec{\Xi} \\
\vec{w} \\
\tilde{U} \\
\tilde{U}\end{array}$ & 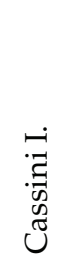 & $\begin{array}{l}\cdot \vec{\Xi} \\
\tilde{W} \\
\tilde{U} \\
\tilde{U}\end{array}$ & 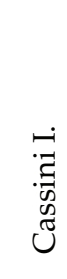 & ũ & & & 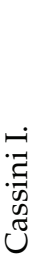 & 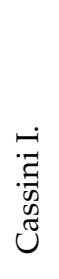 & 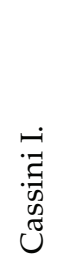 & 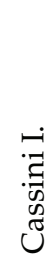 & 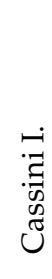 & 8 & c & & & & 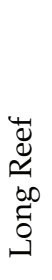 & $\begin{array}{l}\mathscr{0} \\
\mathscr{\sim} \\
0 \\
0 \\
0\end{array}$ & 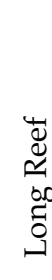 & $\begin{array}{l}\widetilde{\Psi} \\
\widetilde{\mathscr{U}} \\
0.0 \\
0 \\
0\end{array}$ \\
\hline 竞 & $\frac{\stackrel{a}{a}}{\stackrel{\vec{a}}{N}}$ & 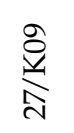 & 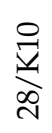 & $\frac{\vec{\nabla}}{\sqrt{2}}$ & $\frac{\stackrel{8}{\vec{v}}}{\Delta}$ & $\underset{m}{\stackrel{ }{\vec{m}}}$ & 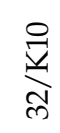 & $\frac{\stackrel{8}{m}}{m}$ & $\frac{9}{7}$ & & & 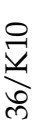 & 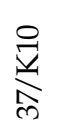 & 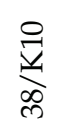 & $\frac{\stackrel{\theta}{\vec{v}}}{\sigma}$ & $\frac{\stackrel{8}{y}}{b}$ & 5 & s & & & & 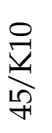 & $\underline{z}$ & 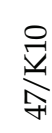 & $\frac{1}{8}$ \\
\hline
\end{tabular}




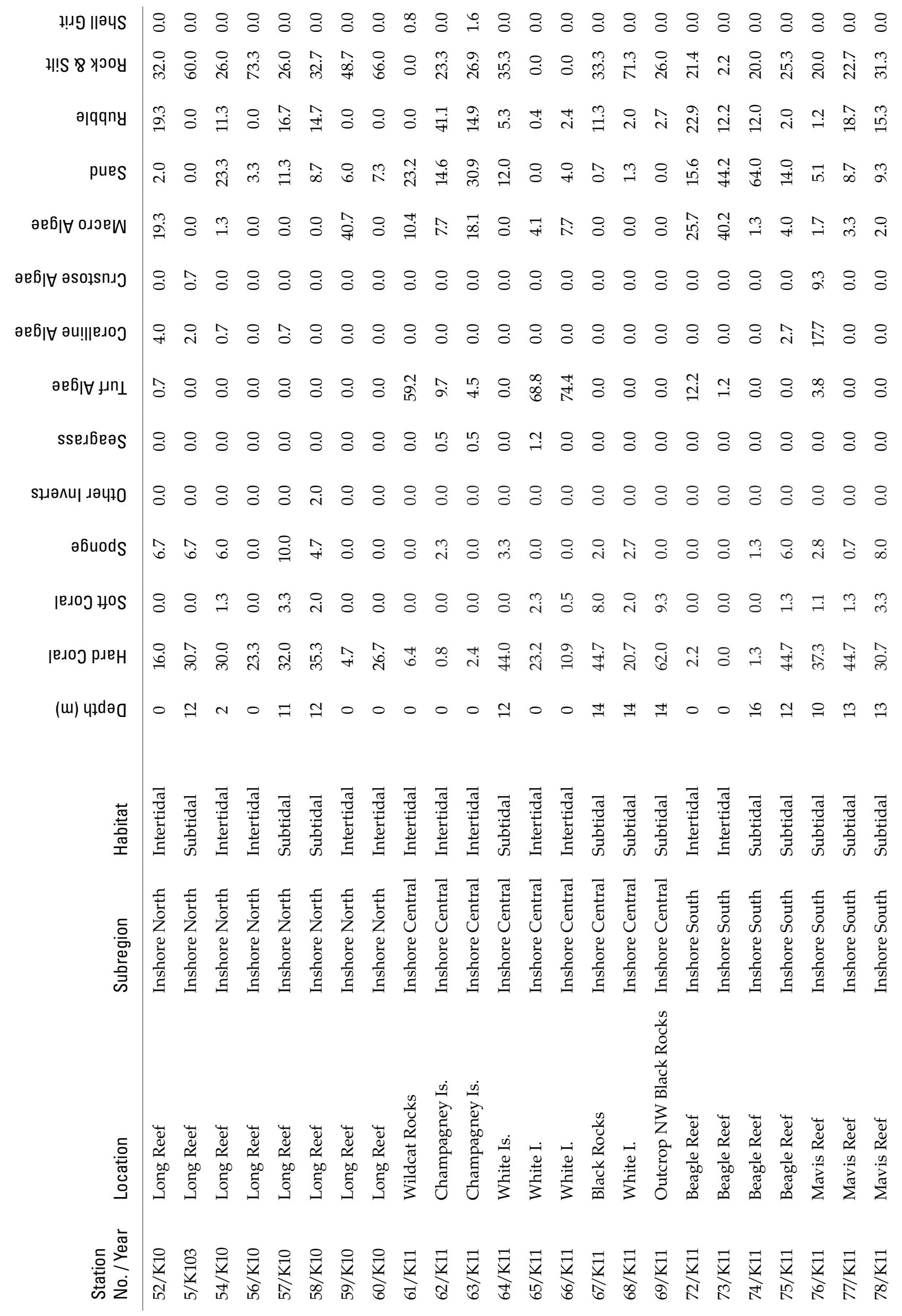




\begin{tabular}{|c|c|c|c|c|c|c|c|c|c|c|c|c|c|c|c|c|c|c|c|c|c|c|c|c|}
\hline 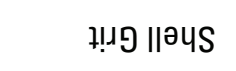 & $\begin{array}{ll}\circ & 0 \\
0\end{array}$ & $\vec{i}$ & 0 & 0 & $\stackrel{L}{0}$ & : & 0 & 0 & & & c & g & E. & : & 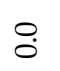 & : & $\stackrel{0}{0}$ & $\stackrel{0}{0}$ & $\stackrel{0}{0}$ & $\stackrel{0}{0}$ & $\stackrel{0}{0}$ & $\stackrel{\circ}{\circ}$ & & 8 \\
\hline HI!S \& ఖ૦о૫ & 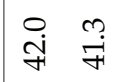 & : & $\stackrel{\circ}{\circ}$ & $\stackrel{9}{9}$ & 8 & 子̊ำ & लें & $\stackrel{0}{\circ}$ & & & $c$ & & ?: & ?ִ & $\stackrel{\infty}{\infty}$ & ते & ن & $\infty_{\infty}^{\infty}$ & $\ddot{\infty}$ & ம0 & + & & & तें \\
\hline ә|વqny & $\stackrel{m}{\rightarrow} \stackrel{m}{m}$ & j & $\begin{array}{l}\infty \\
i \\
i\end{array}$ & 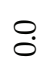 & $\stackrel{\circ}{\sim}$ & $\stackrel{\circ}{\circ}$ & $\widehat{o}$ & $\stackrel{\circ}{\circ}$ & & & $=$ & & $\stackrel{P}{P}$ & $\stackrel{\circ}{\circ}$ & $\stackrel{8}{\circ}$ & $\stackrel{0}{\circ}$ & $\hat{\mathrm{i}}$ & •? & เم & $\hat{o}$ & రి & •P & & 0 \\
\hline pues & 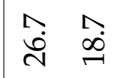 & ఏे & $\ddot{\sim}$ & $\stackrel{\circ}{\circ}$ & $\stackrel{\text { L }}{\stackrel{L}{g}}$ & $\hat{o}$ & $\ddot{\sim}$ & ले & & & $\forall$ & & : & $\ddot{\sim}$ & $\stackrel{0}{0}$ & $\stackrel{\infty}{\infty}$ & o & $\dot{\sim}$ & $\stackrel{10}{2}$ & & ले & $\dot{0}$ & & fें \\
\hline әеб|ఈ ољэеW & $\stackrel{i}{i} \stackrel{0}{0}$ & $\stackrel{\infty}{\sim}$ & ते & $\stackrel{\circ}{\circ}$ & $\infty$ & $\stackrel{\circ}{i}$ & $\stackrel{\circ}{\circ}$ & in & & & m & & & $\stackrel{\circ}{\circ}$ & $\stackrel{\circ}{\circ}$ & $\stackrel{\circ}{\circ}$ & : & लें & : & 0 & $\dot{t}$ & جִ & مج & 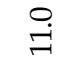 \\
\hline әеб|ఈ әsołsnגว & $\because:$ & $\stackrel{\circ}{\circ}$ & : & : & : & : & $\because$ & $\stackrel{8}{\circ}$ & & & 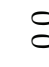 & & $\stackrel{P}{:}$ & $\hat{\curvearrowright}$ & $\vec{m}$ & i & $\vec{i}$ & $\ddot{0}$ & 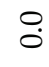 & & 0 & $\underbrace{3}$ & : & \\
\hline әеб|甘 әи!||едоэ & $\begin{array}{ll}0 & 0 \\
0 & 0\end{array}$ & $\stackrel{\circ}{\circ}$ & $\stackrel{\ln }{0}$ & $\stackrel{\circ}{\circ}$ & $\stackrel{\circ}{\circ}$ & $\stackrel{8}{\circ}$ & ز & ?ִ & & & 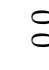 & & $\vec{P}$ & $\underset{\sim}{-}$ & F゙ & Fi & in & ?3 & 8 & $\stackrel{m}{\rightarrow}$ & $\stackrel{m}{i}$ & & אִ & 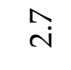 \\
\hline әеб| & $\begin{array}{ll}0 & 0 \\
0 & 0\end{array}$ & ले & ن. & $\stackrel{\circ}{\circ}$ & $\ddot{m}$ & $\stackrel{\circ}{\circ}$ & $\because$ & เo & & & 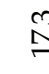 & & P. & ה่ & $\ddot{m}$ & $=$ & $\sigma^{\circ}$ & $\infty$ & ถ่ & $\stackrel{L}{a}$ & $\ddot{\sim}$ & 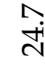 & 3 & \\
\hline ssenbeas & $\because: 0$ & : & $\ddot{0}$ & $\ddot{0}$ & $\ddot{0}$ & $\because$ & : & s & & & & & & $\stackrel{0}{\circ}$ & $\stackrel{0}{\circ}$ & $\stackrel{0}{0}$ & $\dot{0}$ & $\stackrel{\circ}{\circ}$ & $\stackrel{\circ}{\circ}$ & $\stackrel{\circ}{\circ}$ & $\stackrel{\circ}{\circ}$ & 0 & P. & \\
\hline sцәлир дәчғо & $\because 0$ & : & $\stackrel{\circ}{\circ}$ & $\because$ & $\because$ & $\because$ & 0 & 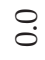 & & & c & & rata & $\stackrel{0}{\circ}$ & $\because$ & $\hat{o}$ & $\because$ & $\stackrel{0}{\circ}$ & $\stackrel{\circ}{0}$ & th & $\stackrel{\circ}{\circ}$ & $\stackrel{0}{0}$ & : & \\
\hline abuods & $\begin{array}{ll}\circ & 0 \\
0 & i\end{array}$ & $\infty^{\infty}$ & $\stackrel{0}{0}$ & $\stackrel{\circ}{+}$ & $\stackrel{0}{0}$ & $\stackrel{\text { i }}{ }$ & ن & c & & & c & & 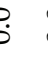 & $\stackrel{0}{0}$ & $\stackrel{0}{0}$ & $\stackrel{\infty}{\infty}$ & $\stackrel{0}{0}$ & 3 & 0 & 0 & $\widehat{0}$ & $\vec{i}$ & 今. & \\
\hline ןגоэ भ०S & $\stackrel{0}{\circ} \stackrel{\circ}{\circ}$ & $\stackrel{\circ}{\circ}$ & $\stackrel{\circ}{0}$ & $\stackrel{?}{\wedge}$ & $\stackrel{0}{0}$ & $\hat{o}$ & $\widehat{o}$ & s & & & 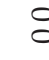 & & P. & $\ddot{m}$ & $\stackrel{0}{0}$ & คें & $\stackrel{0}{0}$ & 0 & $0^{\circ}$ & & 0 & 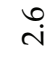 & P. & \\
\hline ן ןеэ рден & $\begin{array}{ll}\circ & \hat{0} \\
\infty & 0 \\
\infty\end{array}$ & $\stackrel{\leftrightarrow}{a}$ & $\stackrel{\circ}{\circ}$ & $\hat{N}$ & 0 & के & $F$ & $\because$ & & 5 & $\infty$ & & P. & $\begin{array}{l}\infty \\
\stackrel{\infty}{9}\end{array}$ & $\stackrel{m}{\stackrel{m}{L}}$ & ڤn & $\ddot{v}$ & $\stackrel{\mathrm{i}}{\mathrm{C}}$ & 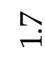 & $\dot{m}$ & 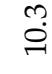 & సิ & 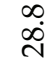 & \\
\hline (ய) पıdəح & $\approx \approx$ & 0 & 0 & f & 0 & $\approx$ & $F$ & 0 & 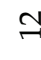 & $c$ & $c$ & ? & $\exists$ & $\exists$ & $\stackrel{ }{\sim}$ & $F$ & $F$ & o & o & I & 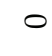 & ra & & \\
\hline 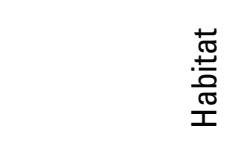 & 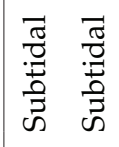 & 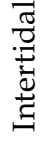 & 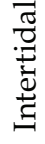 & 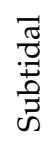 & 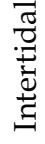 & 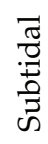 & 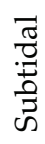 & 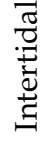 & 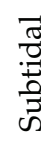 & ? & $\begin{array}{l}\frac{\pi}{2} \\
0 \\
0\end{array}$ & & है & $\begin{array}{l}\frac{\pi}{0} \\
\text { : } \\
\text { की } \\
\text { की }\end{array}$ & 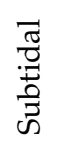 & $\begin{array}{l}\frac{\pi}{0} \\
\frac{0}{0} \\
\frac{0}{0}\end{array}$ & 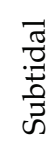 & 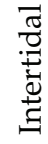 & 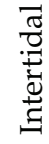 & $\begin{array}{l}\frac{\pi}{0} \\
: 0 \\
0 \\
0 \\
5\end{array}$ & 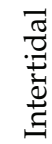 & $\begin{array}{l}\text { : } \\
\overrightarrow{7} \\
\overrightarrow{7}\end{array}$ & $\begin{array}{l}\frac{\pi}{0} \\
0 \\
0 \\
0 \\
0\end{array}$ & 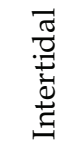 \\
\hline 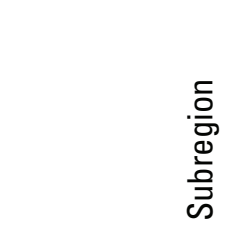 & 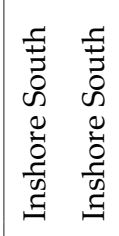 & 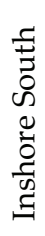 & 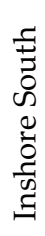 & 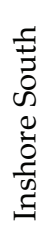 & 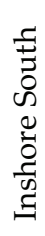 & 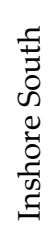 & 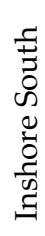 & 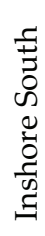 & 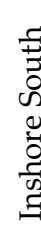 & 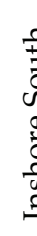 & 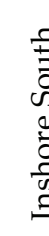 & & 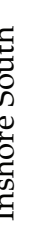 & 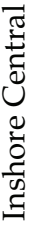 & 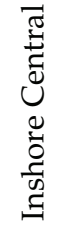 & 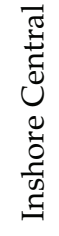 & 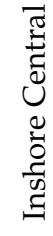 & 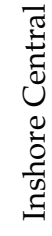 & 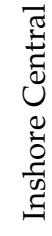 & 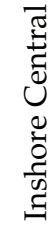 & 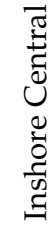 & 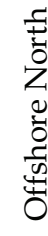 & 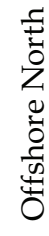 & 蛋 \\
\hline 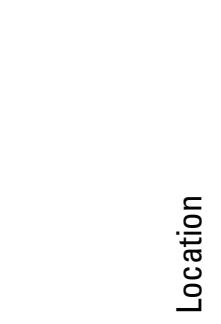 & 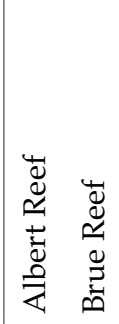 & 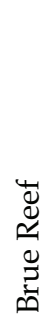 & 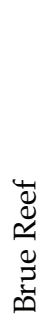 & 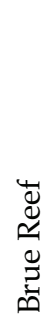 & 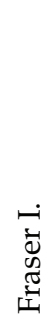 & 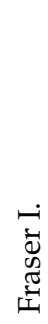 & $\begin{array}{l}\text { ज. } \\
0 \\
3 \\
0 \\
0 \\
0 \\
0 \\
0 \\
0 \\
0 \\
0\end{array}$ & $\begin{array}{l}\text { जी } \\
0 \\
3 \\
0 \\
0 \\
0 \\
0 \\
0 \\
0 \\
0 \\
0\end{array}$ & c & . & $\begin{array}{l}0 \\
.\end{array}$ & & 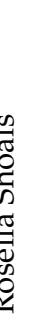 & 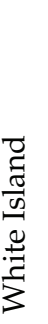 & 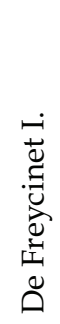 & 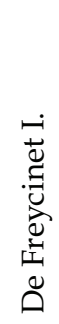 & 蓠 & 苞 & 苞 & $\begin{array}{l}z \\
\text { o } \\
0 \\
0 \\
0 \\
0 \\
0\end{array}$ & $\begin{array}{l}\frac{\pi}{3} \\
\frac{3}{8} \\
3\end{array}$ & $\begin{array}{l}0 \\
0 \\
\text { 3. } \\
0\end{array}$ & & \\
\hline 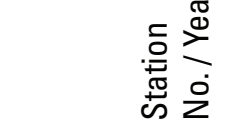 & 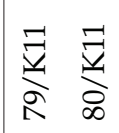 & $\underset{\infty}{\vec{\nabla}}$ & $\underset{\infty}{\stackrel{\vec{\sigma}}{\sigma}}$ & $\underset{\infty}{\vec{\nabla}}$ & $\underset{\infty}{\vec{\nabla}}$ & $\underset{\infty}{\stackrel{\vec{D}}{\infty}}$ & $\frac{\vec{\nabla}}{\infty}$ & $\underset{\infty}{\stackrel{\vec{\sigma}}{\mathbb{N}}}$ & $\forall$ & \pm & $\Xi$ & & & $\frac{\sqrt{v}}{\sigma}$ & $\frac{\overparen{\Xi}}{\not{\Xi}}$ & $\frac{\sqrt{z}}{\frac{\pi}{2}}$ & $\frac{\sqrt[7]{7}}{\delta}$ & $\frac{\sqrt{*}}{\hat{\sigma}}$ & $\underset{\infty}{\vec{y}}$ & $\vec{v}$ & 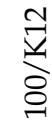 & 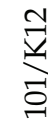 & స్ & \\
\hline
\end{tabular}




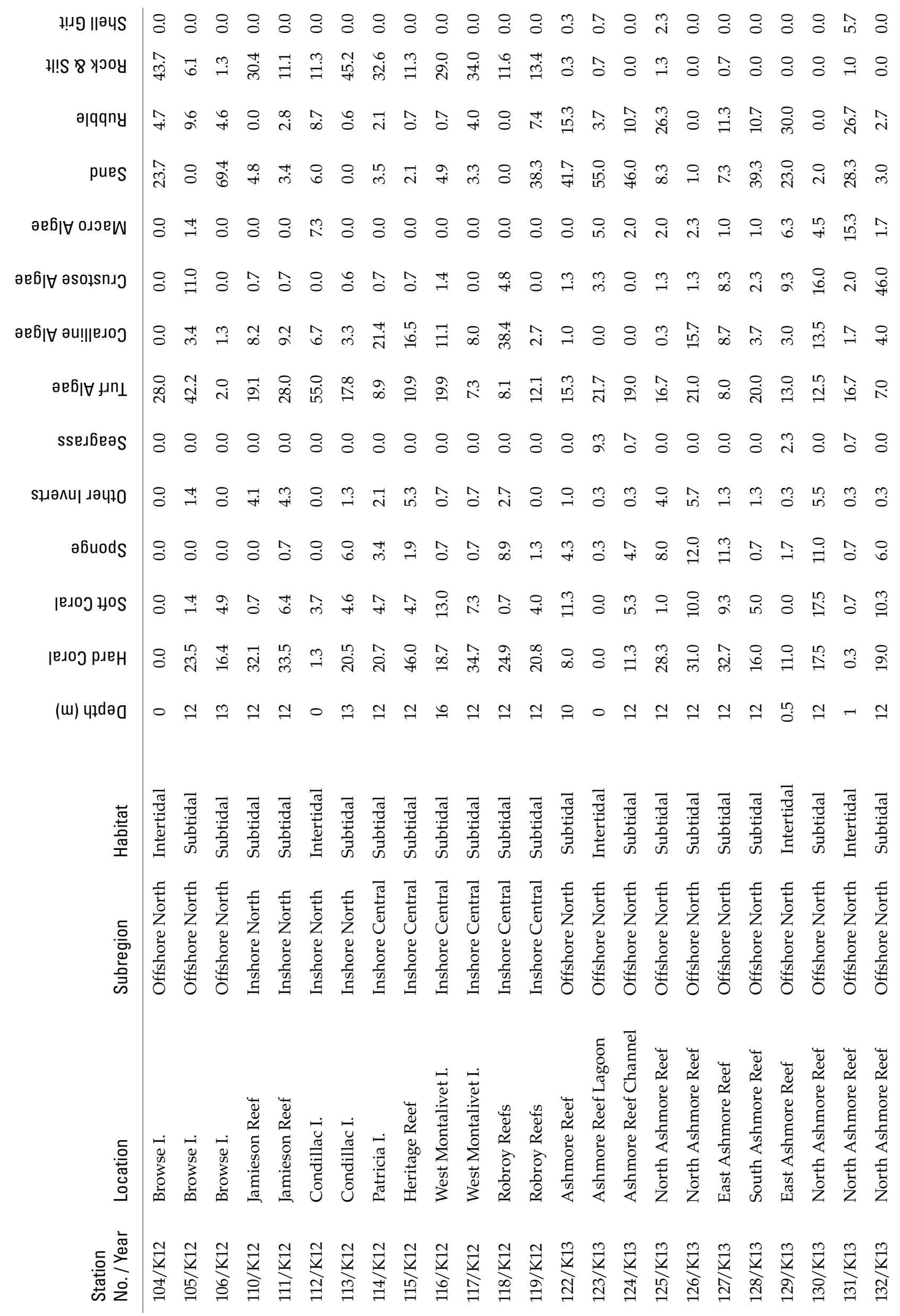




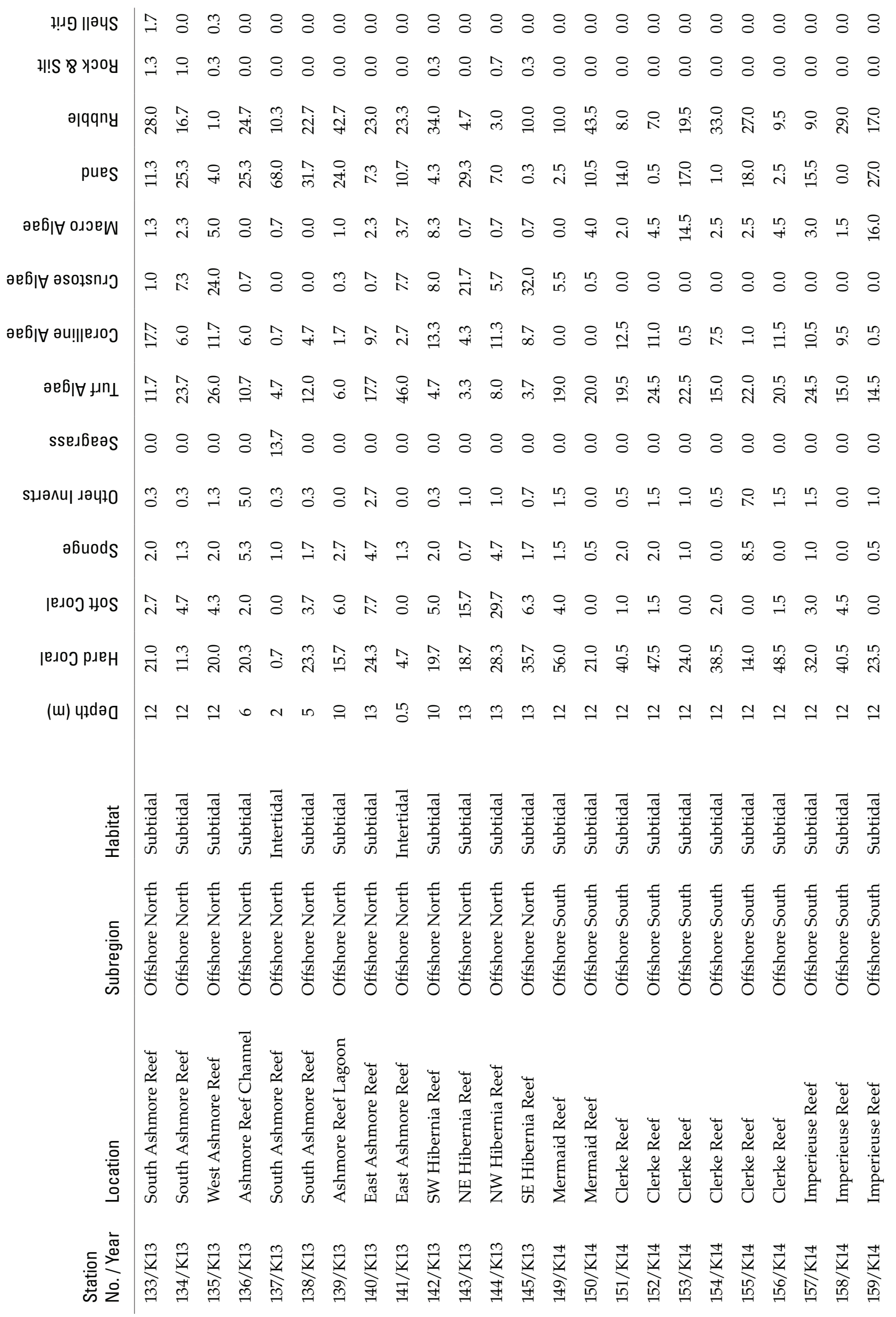




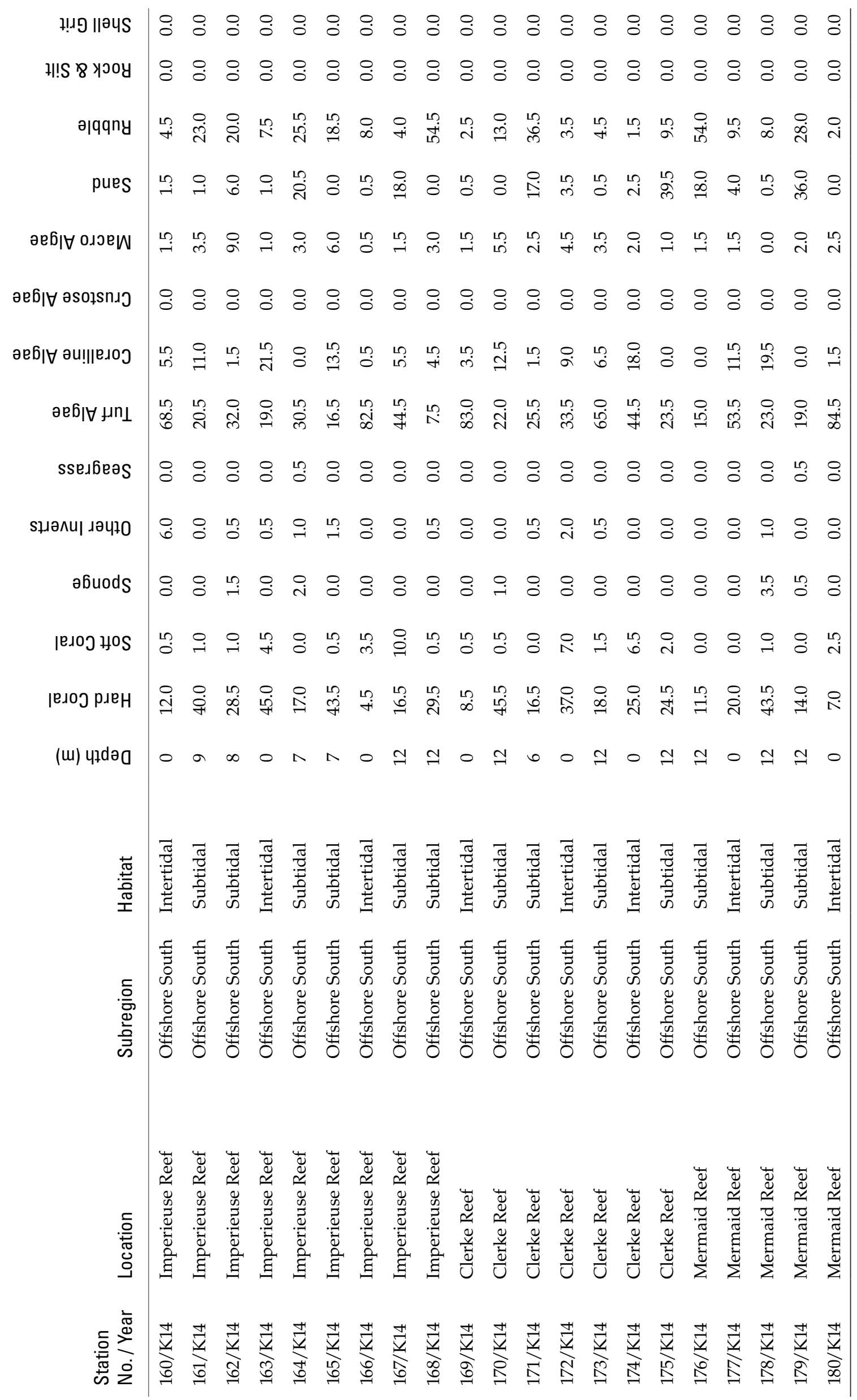

